\title{
Identification of potential structural coherence based on the ceramic material from provincial necropolis II at Ancient Gerulata (SR) using quantitative analyses
}

\author{
Identifikace potenciální strukturální koherence na základě \\ keramického materiálu z provinciálního pohřebiště II v antické \\ Gerulatě (SR) za pomoci kvantitativních analýz
}

- Alina Szabová*, Zuzana Porubčanová -

\section{KEYWORDS}

Gerulata - graves - Roman Period - pottery - volume - shape - statistical analysis - structural coherence

\section{ABSTRACT}

The ceramic vessels from necropolis No. II were redocumented during the ongoing revision of archaeological material from cemeteries belonging to the Roman military fort with civil hinterland - Gerulata. This necropolis contains the highest informative value for both archaeological and anthropological material. Therefore, for the needs of this study, a set of pottery was chosen from that particular site, which consisted of approximately 120 complete various-shaped artefacts to be used for volume calculation. The vessels primarily served for offerings but were also partly used as urns. Drawing and photo documentation was used to create 3D models of the individual artefacts. These visualisations were a data source for the quantitative measurement of the volume variations. Models and volume calculations were created in Blender open-source software before identifying a correlation between vessel shape and volume and the graves in which they were found. The main subject of this research was to identify potential structural coherence within the funerary habits using the univariate statistical analysis produced in PAST 3 open-source software.

\section{*Corresponding author - E-mail address: 489437@mail.muni.cz https://doi.org/10.47382/pv0621-04}

Received 6 February 2021; received in revised form 8 April 2021. Available online 30 June 2021.

Copyright (C) 2021 Czech Acad Sci, Inst Archaeology Brno, and the authors. This is an open access article under the CC BY-NC-ND 4.0 license (https://creativecommons.org/licenses/by-nc-nd/4.0/).

Competing interests: The authors have declared that no competing interests exist.

\section{Site introduction}

Ancient Gerulata is (as part of Limes Romanus) the only archaeological site of its kind in Slovakia. It lies in the territory of the present-day village of Rusovce, which is now part of the capital, Bratislava. In the Roman period, it was a borderline military camp (later a fort) with its own civil hinterland (Schmidtová, Mathédesz 2018, 58), which consisted of vici, villa rustica (Varsik 1999, 215) and the autochthonous agricultural settlement (Hlavatá, Varsik 2019, 429-430). Its immediate vicinity to the border of the northern Danube and its location on the road connecting Carnuntum (Petronell - Bad Deutsch-Altenburg, Austria) and Ad Flexum (Mosonmagyaróvár, Hungary) meant that Gerulata had not only a strategic and military significance but played an important trading role between the Roman Empire and the barbarian societies. Due to the presence of the ford across the river, the probability of a harbour placed somewhere around the camp is extremely high. Unfortunately, constant changes in the river flow across the centuries leave little hope for finding its closer location (Schmidtová, Mathédesz 2018, 57-58). Roman army units occupied Gerulata from the second half of the 1st century AD (Varsik 1996, 22) until the end of the 4 th century or even the beginning of the 5th century AD. Both the civilian settlement and the cemeteries belong to the same time frame (Schmidtová, Mathédesz 2018, 61). A mild hiatus during or shortly after the Marcomannic Wars can be observed inside and outside the camp in the form of a destructive burnt layer (Pichlerová 1983b, 74).

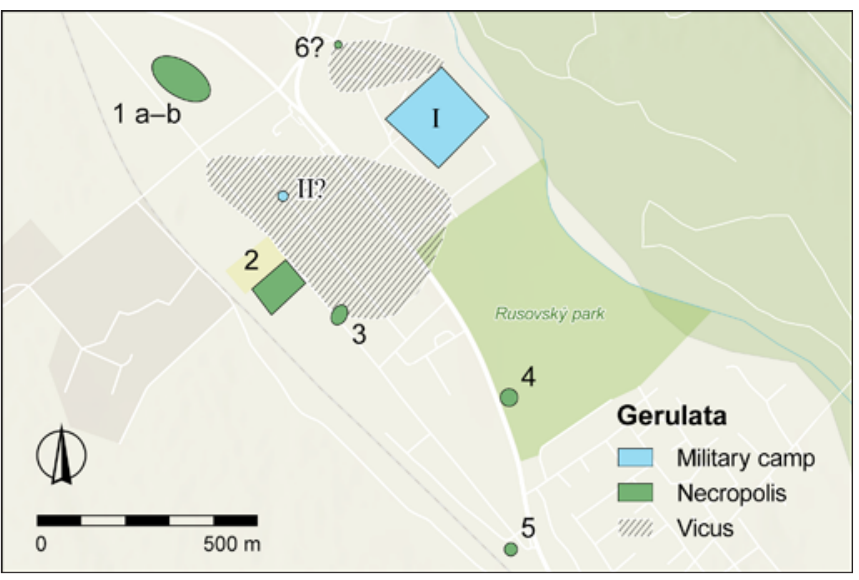

Fig. 1. Topography of ancient Gerulata based on the present state of archaeological excavation. Based on Schmidtová, Mathédesz 2018, 57; Varsik 1996, 131, Abb. 8. Obr. 1. Topografie antické Gerulaty založená na současném stavu výzkumu. Podle Schmidtová, Mathédesz 2018, 57; Varsik 1996, 131, Abb. 8. 
The military camp had four main building phases throughout the Roman period. The first, the earth-and-timber phase, dated between the second half of the 1st and the second half of the 2 nd century AD, was characterised by a typical double-pointed ditch and a rampart with a wooden palisade (Varsik 1996, 24). This was possibly established by the Cohors $V$ Callaecorum Lucensium, according to the finds of stamped bricks (Schmidtová, Mathédesz 2016, 126-127). However, at the beginning of the 2nd century AD, Ala I Cannanefatium arrived from the Lower Rhine region, which caused construction changes in the inner area of the camp. This unit remained in Gerulata until the beginning of the 4th century AD. During the Marcomannic Wars in the second half of the 2nd century AD, a large stone castell was built in its place (Varsik 1996, 26). In this period, temporary camp No. II also existed about $300 \mathrm{~m}$ from the permanent camp (Varsik 1996, 31). The third phase lasted from the end of the 3rd to the first half of the 4th century AD. The castell was partially reduced, and the fortification wall was added. The final phase is distinguished by the late antique fort, which is dated from the second half of the 4th to the beginning of the 5th century AD (Varsik 1996, 28-29). By then, Gerulata was inhabited by a new unit called Equites Sagittarii equestrian archers (Varsik 1996, 37). During the gradual decay of Limes Romanus, these troops completely abandoned Gerulata (Schmidtová, Mathédesz 2018, 61).

Several burial places were created during the Roman occupation, possibly along the roads leading from the camp (Fig. 1). Five to six cemeteries (Hlavenková et al. 2015, 139-143) and several isolated graves have been discovered up to the present day in residential and industrial zones (Pichlerová 1983a, 208). Cemeteries No. Ia, II and V are from the Early Roman period; the later phase includes No. Ib, III, IV and eventually VI

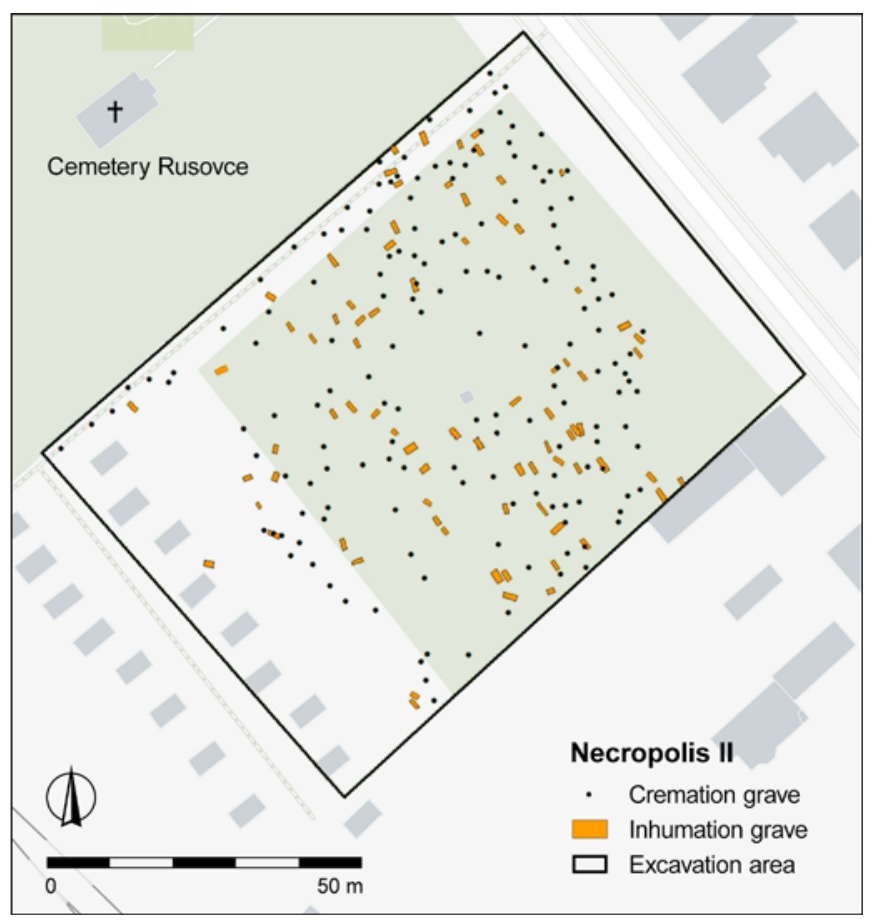

Fig. 2. Grave distribution in the main part of the researched territory of necropolis II (excavation in 1949 and 1968-1973). The exact location of the later discovered graves was not published. Based on the original distribution plan from Pichlerová 1981.

Obr. 2. Distribuce hrobů v hlavní prozkoumané části pohřebiště II (výzkumy v letech 1949 a 1968-1973). Přesná lokace později objevených hrobů není publikována. Založeno na originálním distribučním plánu podle Pichlerová 1981.
(Hlavenková et al. 2015, 140-143). There is a definite possibility that some of the burial grounds (especially II and III) are only fractions of one large long-lasting necropolis (Varsik 1996, 36). However, this will have to be proved by further excavations. Civilians and soldiers were probably buried together without any differences (Pichlerová 1983b, 77).

In this study, we used archaeological material from necropolis II, which is situated next to the modern cemetery (Fig. 2). The necropolis has the highest number of well-documented graves (258) with 88 inhumation and 170 cremation burials discovered there to date (Hlavenková et al. 2015, 142). The inhumation burials were dominated by simple pits although brick tombs and alcove or shaft graves were also present. The cremation graves consisted of simple pits, urn graves, pits with or without cremation residuals and busta (Pichlerová 1981, 21-26). Burying began there under the rule of the Flavian dynasty and ended some time at the beginning of the 3rd century AD (Pichlerová 1981, 17-18). The main excavation took place between 1968 and 1973 although a couple of graves were already discovered in 1949 and earlier (Pichlerová 1981, 13). Several more graves were later identified in the 1980s (Pichlerová 1983a, 209) and the 2000s by rescue excavations (Schmidtová, Vorlíčková 2006, 175). The unusual biritual character of this cemetery could have been hypothetically caused in this time period by the presence of the autochthonous population although a different explanation is also possible. For example, the influence of eastern religious cults, the tradition of certain social groups, insufficient exploration of similar sites or a local anomaly (Krekovič 1992, 73-75).

\section{Data set and formulation of hypotheses}

A collection of 121 ceramic vessels (Tab. 1) deposited in the Archaeological museum of Slovak National Museum (hereinafter referred to as SNM) was chosen for the volume calculation. Most of the vessels were complete, but several were preserved only fragmentary. In some cases (e.g., 5, 23, 25), we were able to reconstruct the missing part of the original proportion due to the fieldwork documentation (archive of the Archaeological museum SNM) and calculate the absolute volumes. However, sometimes (e.g., 18, 67, 98) it was possible to only reconstruct a major part of the vessel, thereby only the minimum volume was calculated. This collection contains typical fine yellow ware and both fine and coarse-grain grey ware (Krekovič 1998, 42-44). Terra sigillata, mostly from Lezoux, Rheinzabern and Westerndorf, was also present. Types such as Drag. 18/31 (No. 30), Drag. 33 (No. 36), Drag. 36 (No. 41) and Drag. 37 (No. 34) appeared in the spectrum (Gabler, Pichlerová 1996).

Nevertheless, it was necessary to adequately classify the material and formulation of the key hypotheses before the volume calculation and statistical analysis (Neustupný 2007, 136). The fiveshape group categorisation proved to be the most suitable and was also optimal for the following analyses. The first and quite homogeneous group involved 26 jugs and pitchers (Fig. 3, 4) with heights between $15.8-40 \mathrm{~cm}$, a maximum bulge of $10-20 \mathrm{~cm}$, a mouth diameter of $5-8.33 \mathrm{~cm}$ and a base diameter of $5.9-8.98 \mathrm{~cm}$. The second group consisted of 28 bowls and plates (Fig. 5, 6) with heights between $3.2-14.5 \mathrm{~cm}$ and diameters of $7.2-26.5 \mathrm{~cm}$. Even though the bowls are much higher than the plates, their volumes are similar because of the generally wider diameter of the plates. All the representatives of terra sigillata belong to this shape group. The third group is the largest (36 pieces) and also a quite uniform group, which contains convex forms, such as ovoid and pot-shaped vessels (Fig. 7, 8). The height of these vessels ranges between 9-22 cm, with a maximum bulge of $8-18 \mathrm{~cm}$, a mouth diameter of $8.2-15.5 \mathrm{~cm}$ and a base diameter of $3.6-8.1 \mathrm{~cm}$. 


\begin{tabular}{|c|c|c|c|c|c|c|c|c|c|c|c|}
\hline No. & Inv. No. & $\begin{array}{l}\text { Vessel } \\
\text { shape }\end{array}$ & $\begin{array}{l}\text { Absolute } \\
\text { height } \\
(\mathrm{cm})\end{array}$ & $\begin{array}{l}\text { Absolute } \\
\text { volume } \\
(\mathrm{ml})\end{array}$ & Grave No. & Burial type & Grave type & Gender & Age & $\begin{array}{l}\text { Vessel location } \\
\text { (Grave part) }\end{array}$ & $\begin{array}{l}\text { Grave } \\
\text { dating (AD) }\end{array}$ \\
\hline 1 & 21099 & Jug & 43 & 7208.14 & 63 & Cremation & $\begin{array}{l}\text { Pit with cremation } \\
\text { residuals }\end{array}$ & Unknown & Adult & ? & $100-200$ \\
\hline 2 & 21052 & Jug & 39 & 5353.4 & LXIII & Inhumation & Simple pit & Male & Adult & Right lower p. & $50-200$ \\
\hline 3 & 21209 & Jug & 37.5 & 5517.4 & 127 & Cremation & Simple pit & Unknown & Adult & Middle p. & $50-200$ \\
\hline 4 & 21237 & Jug & 36 & 4058.1 & 97 & Cremation & Bustum & Unknown & Adult & Left lower $\mathrm{p}$. & $50-100$ \\
\hline 5 & 21283 & Jug & 34 & 4398.78 & 104 & Cremation & $\begin{array}{l}\text { Pit with cremation } \\
\text { residuals }\end{array}$ & Unknown & Adult & Left upper p. & $100-150$ \\
\hline 6 & 21282 & Jug & 32 & 3060.71 & 104 & Cremation & $\begin{array}{l}\text { Pit with cremation } \\
\text { residuals }\end{array}$ & Unknown & Adult & Upper p. & $100-150$ \\
\hline 7 & 20986 & Jug & 30 & 2610.4 & XXVII & Inhumation & Simple pit & Unknown & Child & Middle upper p. & $50-150$ \\
\hline 8 & 14878 & Jug & 30 & 2180 & III & Inhumation & Simple pit & Male & Adult & Left lower p. & $50-100$ \\
\hline 9 & 21073 & Jug & 29 & 2346.73 & LXXXVI & Inhumation & Simple pit & Male & Adult & Middle lower p. & $150-250$ \\
\hline 10 & 21450 & Jug & 28.8 & 2113.03 & 159 & Cremation & Simple pit & Unknown & Unknown & ? & $50-200$ \\
\hline 11 & 15381 & Jug & 28 & 2156.2 & 43 & Cremation & Bustum & Unknown & Adult & Right lower p. & $50-150$ \\
\hline 12 & 15326 & Jug & 27 & 2248 & 29 & Cremation & Bustum & Unknown & Adult & Middle p. & $50-200$ \\
\hline 13 & 14870 & Jug & 27 & 2198 & I & Inhumation & Simple pit & Unknown & Child & Right lower p. & $100-200$ \\
\hline 14 & 14918 & Jug & 26.5 & 1003 & XV & Inhumation & Simple pit & Unknown & Child & Right upper p. & $50-150$ \\
\hline 15 & 21102 & Jug & 26 & 1885.63 & 64 & Cremation & $\begin{array}{l}\text { Pit with cremation } \\
\text { residuals }\end{array}$ & Unknown & Adult & ? & $50-200$ \\
\hline 16 & 24227 & Jug & 26 & 2178.54 & 171 & Cremation & $\begin{array}{l}\text { Pit with cremation } \\
\text { residuals }\end{array}$ & Unknown & Unknown & ? & $50-200$ \\
\hline 17 & 21449 & Jug & 24.4 & 1481.49 & 158 & Cremation & $\begin{array}{l}\text { Pit with cremation } \\
\text { residuals }\end{array}$ & Unknown & Adult & Middle $\mathrm{p}$. & $50-200$ \\
\hline 18 & 24230 & Jug & 24 & 2816.46 & 172 & Cremation & $\begin{array}{l}\text { Pit without } \\
\text { cremation residuals }\end{array}$ & Unknown & Unknown & ? & $50-200$ \\
\hline 19 & 21016 & Jug & 24 & 1299 & XLII & Inhumation & Simple pit & Male & Adult & Right upper p. & $50-150$ \\
\hline 20 & 15380 & Jug & 21.5 & 1011.96 & 43 & Cremation & Bustum & Unknown & Adult & Middle p. & $50-150$ \\
\hline 21 & 21044 & Jug & 21 & 988.08 & LVIII & Inhumation & Simple pit & Unknown & Child & Middle lower p. & $100-00$ \\
\hline 22 & 24215 & Pitcher & 20.3 & 1014.85 & 168 & Cremation & $\begin{array}{l}\text { Pit without } \\
\text { cremation residuals }\end{array}$ & Unknown & Unknown & ? & $100-200$ \\
\hline 23 & 20908 & Jug & 20 & 1473 & 49 & Cremation & Urn grave & Unknown & Adult & ? & $50-200$ \\
\hline 24 & 21020 & Jug & 20 & 709.05 & XLIII & Inhumation & Simple pit & Unknown & Child & Middle upper p. & $100-150$ \\
\hline 25 & 21251 & Jug & 19.5 & 1176.5 & 97 & Cremation & Bustum & Unknown & Adult & Left lower p. & $50-100$ \\
\hline 26 & 14911 & Pitcher & 15.8 & 617.8 & XIII & Inhumation & Brick chamber & Unknown & Child & Right upper p. & $50-150$ \\
\hline 27 & 15346 & Bowl & 14.5 & 3513.7 & 33 & Cremation & $\begin{array}{l}\text { Pit with cremation } \\
\text { residuals }\end{array}$ & Female & Adult & Upper p. & $100-200$ \\
\hline 28 & 21458 & Bowl & 10.4 & 1485.43 & 155 & Cremation & $\begin{array}{l}\text { Pit with cremation } \\
\text { residuals }\end{array}$ & Unknown & Adult & ? & $100-200$ \\
\hline 29 & 24229 & Bowl & 8.5 & 1453.52 & 172 & Cremation & $\begin{array}{l}\text { Pit without } \\
\text { cremation residuals }\end{array}$ & Unknown & Unknown & $?$ & $50-200$ \\
\hline 30 & 21217 & Bowl & 8.5 & 1682.64 & 94 & Cremation & $\begin{array}{l}\text { Pit with cremation } \\
\text { residuals }\end{array}$ & Unknown & Adult & Middle p. & $150-250$ \\
\hline 31 & 21308 & Bowl & 8.3 & 851.5 & 111 & Cremation & Simple pit & Unknown & Adult & ? & $100-150$ \\
\hline 32 & 21308 & Bowl & 8.2 & 923.87 & 111 & Cremation & Simple pit & Unknown & Adult & ? & $100-150$ \\
\hline 33 & 14882 & Bowl & 6.88 & 82.12 & IV & Inhumation & Simple pit & Unknown & Child & Right upper p. & $50-150$ \\
\hline 34 & 21103 & Bowl & 6.5 & 517.05 & 66 & Cremation & $\begin{array}{l}\text { Pit with cremation } \\
\text { residuals }\end{array}$ & Unknown & Adult & Upper p. & $100-150$ \\
\hline 35 & 20925 & Bowl & 6.15 & 256.89 & 51 & Cremation & $\begin{array}{l}\text { Pit with cremation } \\
\text { residuals }\end{array}$ & Female & Adult & ? & $100-150$ \\
\hline 36 & 21131 & Bowl & 5.7 & 105.93 & 75 & Cremation & $\begin{array}{l}\text { Pit with cremation } \\
\text { residuals }\end{array}$ & Unknown & Adult & ? & $100-200$ \\
\hline 37 & 15383 & Bowl & 5.4 & 863 & 43 & Cremation & Bustum & Unknown & Adult & Left upper p. & $50-150$ \\
\hline 38 & 15384 & Bowl & 5.2 & 354.4 & 43 & Cremation & Bustum & Unknown & Adult & Middle p. & $50-150$ \\
\hline 39 & 15385 & Bowl & 5 & 276.1 & 43 & Cremation & Bustum & Unknown & Adult & Left upper p. & $50-150$ \\
\hline 40 & 15386 & Bowl & 4.8 & 298.4 & 43 & Cremation & Bustum & Unknown & Adult & Left upper p. & $50-150$ \\
\hline 41 & 21225 & Bowl & 4.5 & 446.36 & 95 & Cremation & Simple pit & Unknown & Adult & $?$ & $50-150$ \\
\hline 42 & 21032 & Bowl & 4.5 & 471.07 & LI & Inhumation & Simple pit & Unknown & Child & Left middle $\mathrm{p}$. & $100-150$ \\
\hline
\end{tabular}




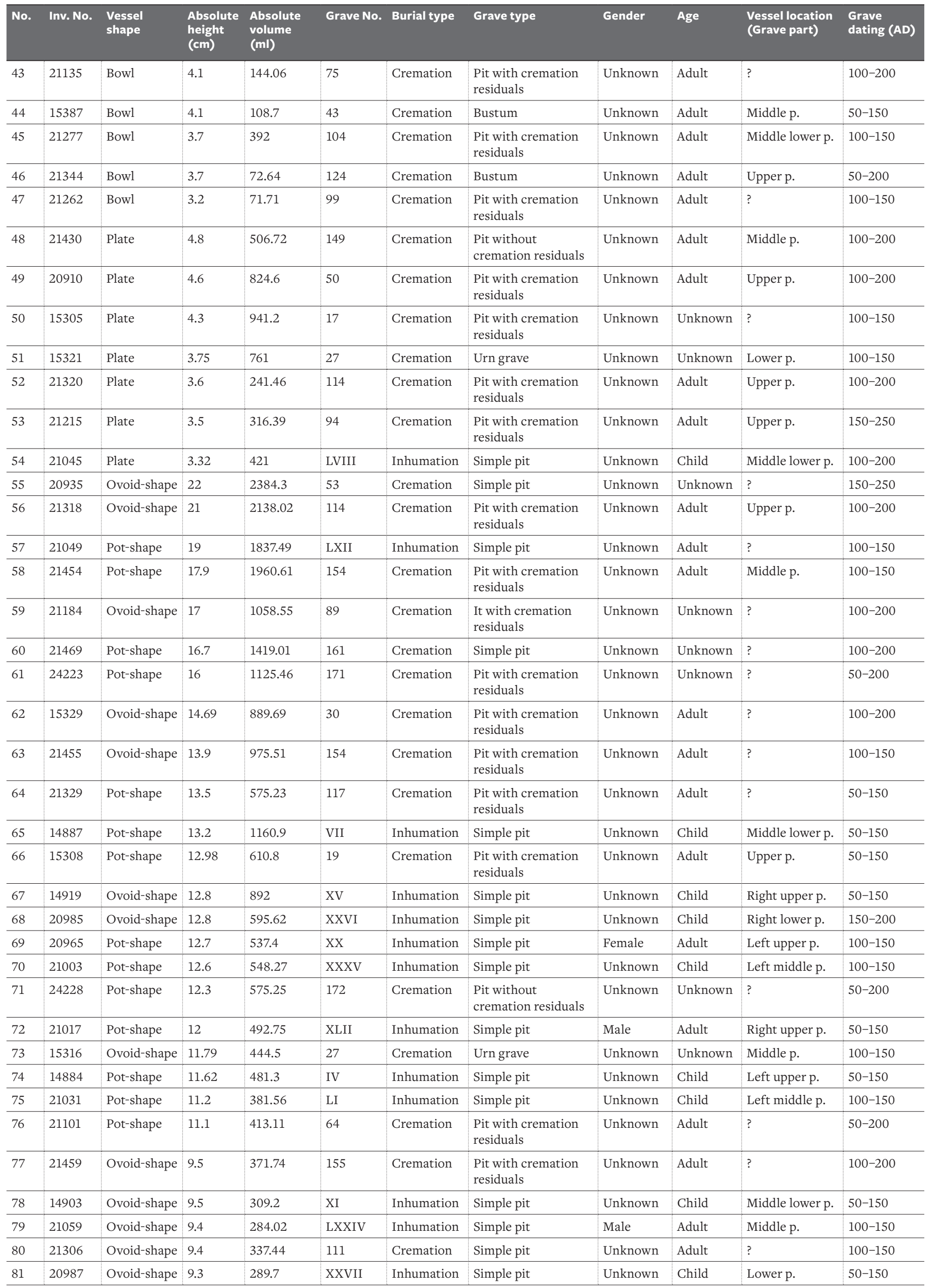




\begin{tabular}{|c|c|c|c|c|c|c|c|c|c|c|c|}
\hline No. & Inv. No. & $\begin{array}{l}\text { Vessel } \\
\text { shape }\end{array}$ & $\begin{array}{l}\text { Absolute } \\
\text { height } \\
(\mathrm{cm})\end{array}$ & $\begin{array}{l}\text { Absolute } \\
\text { volume } \\
(\mathrm{ml})\end{array}$ & Grave No. & Burial type & Grave type & Gender & Age & $\begin{array}{l}\text { Vessel location } \\
\text { (Grave part) }\end{array}$ & $\begin{array}{l}\text { Grave } \\
\text { dating (AD) }\end{array}$ \\
\hline 82 & 14880 & Ovoid-shape & 9.05 & 283 & III & Inhumation & Simple pit & Male & Adult & Left lower $\mathrm{p}$. & $50-100$ \\
\hline 83 & 21439 & Ovoid-shape & 9.05 & 288.71 & 156 & Cremation & $\begin{array}{l}\text { Pit without } \\
\text { cremation residuals }\end{array}$ & Unknown & Adult & ? & $50-200$ \\
\hline 84 & 21270 & Ovoid-shape & 9.05 & 214.27 & 101 & Cremation & Urn grave & Unknown & Child & ? & $150-200$ \\
\hline 85 & 15317 & Ovoid-shape & 9 & 284.2 & 27 & Cremation & Urn grave & Unknown & Unknown & Lower p. & $100-150$ \\
\hline 86 & 21274 & Ovoid-shape & 9 & 293.33 & 102 & Cremation & $\begin{array}{l}\text { Pit with cremation } \\
\text { residuals }\end{array}$ & Unknown & Adult & Upper p. & $50-100$ \\
\hline 87 & 14879 & Ovoid-shape & 8.9 & 280 & III & Inhumation & Simple pit & Male & Adult & Middle p. & $50-100$ \\
\hline 88 & 21074 & Ovoid-shape & 8.6 & 323.61 & LXXXVII & Inhumation & Simple pit & Unknown & Child & $?$ & $50-200$ \\
\hline 89 & 15287 & Ovoid-shape & 7.9 & 208 & 10 & Cremation & Simple pit & Unknown & Unknown & $?$ & $50-100$ \\
\hline 90 & 15320 & Ovoid-shape & 6.9 & 115.3 & 27 & Cremation & Urn grave & Unknown & Unknown & Lower p. & $100-150$ \\
\hline 91 & 21216 & Vase & 33.5 & 6345.82 & 94 & Cremation & $\begin{array}{l}\text { Pit with cremation } \\
\text { residuals }\end{array}$ & Unknown & Adult & Middle p. & $150-250$ \\
\hline 92 & 15296 & Vase & 19 & 968.4 & 14 & Cremation & $\begin{array}{l}\text { Pit without } \\
\text { cremation residuals }\end{array}$ & Unknown & Adult & ? & $150-250$ \\
\hline 93 & 24224 & Vase & 17 & 1334.62 & 171 & Cremation & $\begin{array}{l}\text { Pit with cremation } \\
\text { residuals }\end{array}$ & Unknown & Unknown & ? & $50-200$ \\
\hline 94 & 14883 & Vase & 11.9 & 128.72 & IV & Inhumation & Simple pit & Unknown & Child & Left upper $p$. & $50-150$ \\
\hline 95 & 14925 & $\begin{array}{l}\text { Amphora- } \\
\text { shape }\end{array}$ & 10.7 & 270 & II & Inhumation & Simple pit & Unknown & Child & $?$ & $150-250$ \\
\hline 96 & 15301 & Cup & 24 & 1233.8 & 15 & Cremation & $\begin{array}{l}\text { Pit with cremation } \\
\text { residuals }\end{array}$ & Unknown & Adult & ? & $150-250$ \\
\hline 97 & 20912 & Cup & 22.5 & 1703.4 & 50 & Cremation & $\begin{array}{l}\text { Pit with cremation } \\
\text { residuals }\end{array}$ & Unknown & Adult & Lower p. & $100-200$ \\
\hline 98 & 15395 & Cup & 12.99 & 782 & 13 & Cremation & Simple pit & Unknown & Unknown & $?$ & $100-200$ \\
\hline 99 & 20992 & Cup & 16.5 & 775.4 & XXVIII & Inhumation & Alcove grave & Male & Adult & Left upper $\mathrm{p}$. & $100-200$ \\
\hline 100 & 14871 & Cup & 9.25 & 206.8 & I & Inhumation & Simple pit & Unknown & Child & Left middle $\mathrm{p}$. & $100-200$ \\
\hline 101 & 15319 & Cup & 8.6 & 143.7 & 27 & Cremation & Urn grave & Unknown & Unknown & Upper p. & $100-150$ \\
\hline 102 & 21307 & Cup & 4.1 & 89.59 & 111 & Cremation & Simple pit & Unknown & Adult & ? & $100-150$ \\
\hline 103 & 15351 & Urn & 29 & 5705.9 & 34 & Cremation & Urn grave & Male & Adult & $?$ & $50-150$ \\
\hline 104 & 20907 & Urn & 27 & 6427 & 49 & Cremation & Urn grave & Unknown & Adult & ? & $50-200$ \\
\hline 105 & 21276 & Urn & 24 & 3244.59 & 104 & Cremation & Urn grave & Unknown & Adult & Left middle $\mathrm{p}$. & $100-150$ \\
\hline 106 & 21147 & Urn & 23 & 2398.39 & 78 & Cremation & Urn grave & Unknown & Child & $?$ & $100-150$ \\
\hline 107 & 21295 & Urn & 22.4 & 3757.8 & 108 & Cremation & Urn grave & Unknown & Adult & $?$ & $100-150$ \\
\hline 108 & 21106 & Urn & 22 & 2846.27 & 68 & Cremation & Urn grave & Unknown & Unknown & $?$ & $100-150$ \\
\hline 109 & 21290 & Urn & 21.55 & 2848.51 & 107 & Cremation & Urn grave & Unknown & Child & $?$ & $50-150$ \\
\hline 110 & 21434 & Urn & 21.49 & 2674.63 & 150 & Cremation & Urn grave & Unknown & Child & $?$ & $100-150$ \\
\hline 111 & 15379 & Urn & 21 & 3570.6 & 43 & Cremation & Urn grave & Unknown & Adult & Middle p. & $50-150$ \\
\hline 112 & 21325 & Urn & 20.91 & 2414.63 & 115 & Cremation & Urn grave & Unknown & Unknown & $?$ & $100-150$ \\
\hline 113 & 20930 & Urn & 19 & 3508.39 & 52 & Cremation & Urn grave & Unknown & Adult & $?$ & $50-200$ \\
\hline 114 & 21268 & Urn & 18.75 & 1865.71 & 101 & Cremation & Urn grave & Unknown & Child & ? & $150-200$ \\
\hline 115 & 21288 & Urn & 18.6 & 2082.57 & 106 & Cremation & Urn grave & Unknown & Child & $?$ & $50-200$ \\
\hline 116 & 21129 & Urn & 18 & 1414.34 & 74 & Cremation & Urn grave & Unknown & Adult & ? & $50-200$ \\
\hline 117 & 21195 & Urn & 17 & 2452.74 & 92 & Cremation & Urn grave & Unknown & Adult & $?$ & $50-200$ \\
\hline 118 & 24222 & Urn & 16.2 & 1165.37 & 170 & Cremation & Urn grave & Unknown & Unknown & ? & $50-200$ \\
\hline 119 & 21158 & Urn & 15.23 & 814.19 & 84 & Cremation & Urn grave & Unknown & Child & $?$ & $150-200$ \\
\hline 120 & 24221 & Urn & 14 & 857.99 & 169 & Cremation & Urn grave & Unknown & Unknown & $?$ & $50-200$ \\
\hline 121 & 15318 & Urn & 8.5 & 197.5 & 27 & Cremation & Urn grave & Unknown & Unknown & Middle p. & $100-150$ \\
\hline
\end{tabular}

Tab. 1. Pottery data set with calculated absolute volumes (No. = vessel number in the photo/model tables;

Tab. 1. Keramický datový soubor svypočtenými absolutními objemy (No. = číslo nádoby ve fotografických/modelových tabulkách; Inv. No. = číslo nádoby vinventáři Archeologického múzea Slovenského národného múzea, dále jako SNM. 

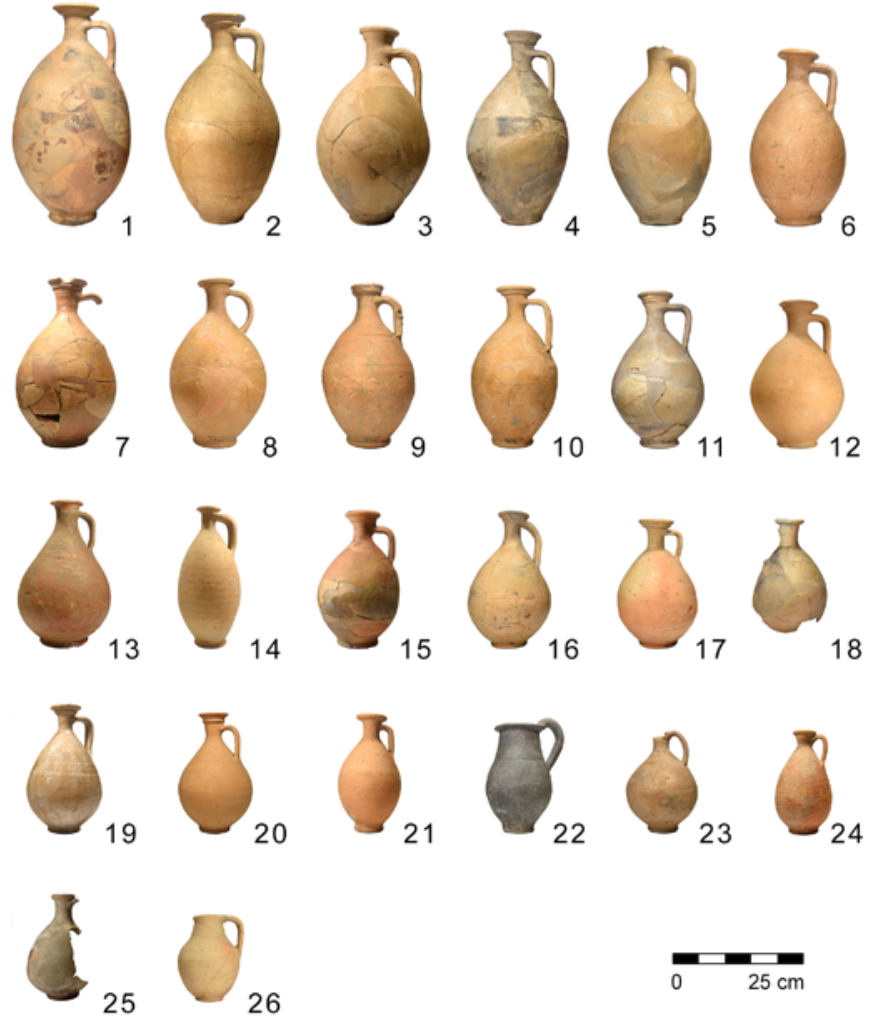

Fig. 3. Pottery set with calculated volumes. Group No. 1: Jugs and pitchers. Deposited in the Archaeological museum SNM. Photo by A. Szabová.

Obr. 3. Keramický soubor svypočtenými absolutními objemy. Skupina č. 1: Džbány a konvice. Uloženo v Archeologickém múzeu SNM. Foto A. Szabová.
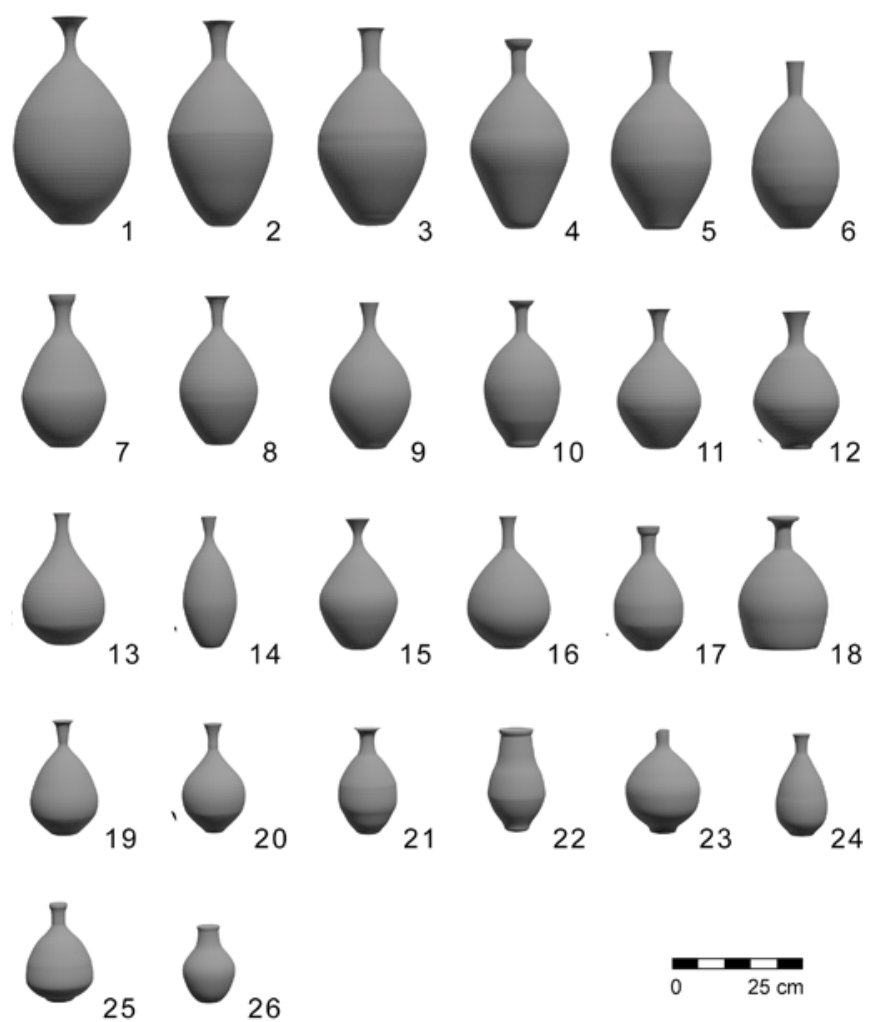

26

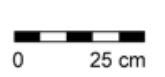

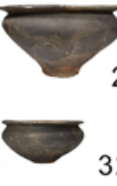
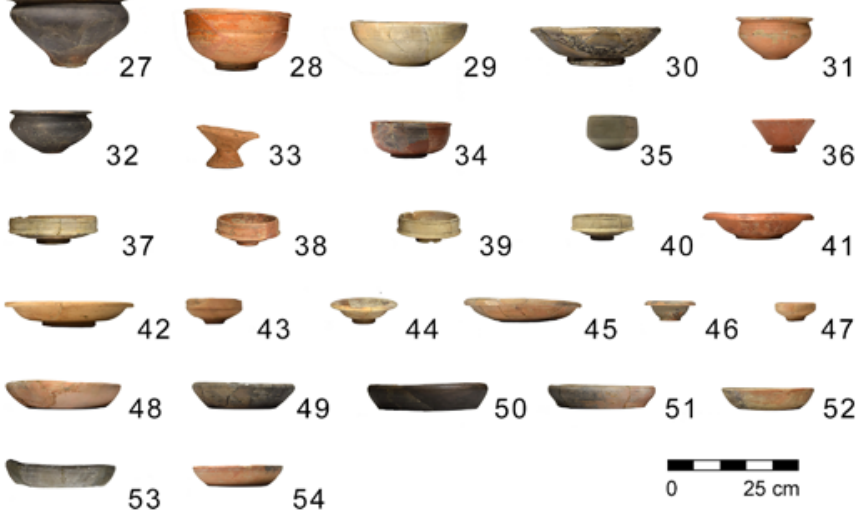

Fig. 5. Pottery set with calculated volumes. Group No. 2: Bowls and plates. Deposited in the Archaeological museum SNM. Photo by A. Szabová.

Obr. 5. Keramický soubor s vypočtenými absolutními objemy. Skupina č. 2: Misky a talíře. Uloženo v Archeologickém múzeu SNM. Foto A. Szabová.
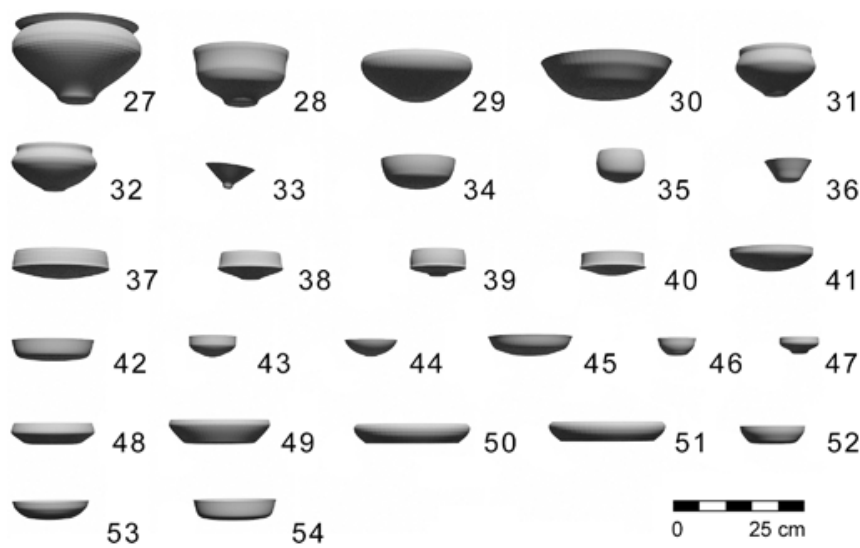

Fig. 6. Generated models of the pottery set with calculated volumes.

Group No. 2: Bowls and plates. Deposited in the Archaeological museum SNM. Models by Z. Porubčanová.

Obr. 6. Vygenerované modely keramického souboru s vypočtenými absolutními objemy. Skupina č. 2: Misky a talíre. Uloženo v Archeologickém múzeu SNM. Modely Z. Porubčanová.
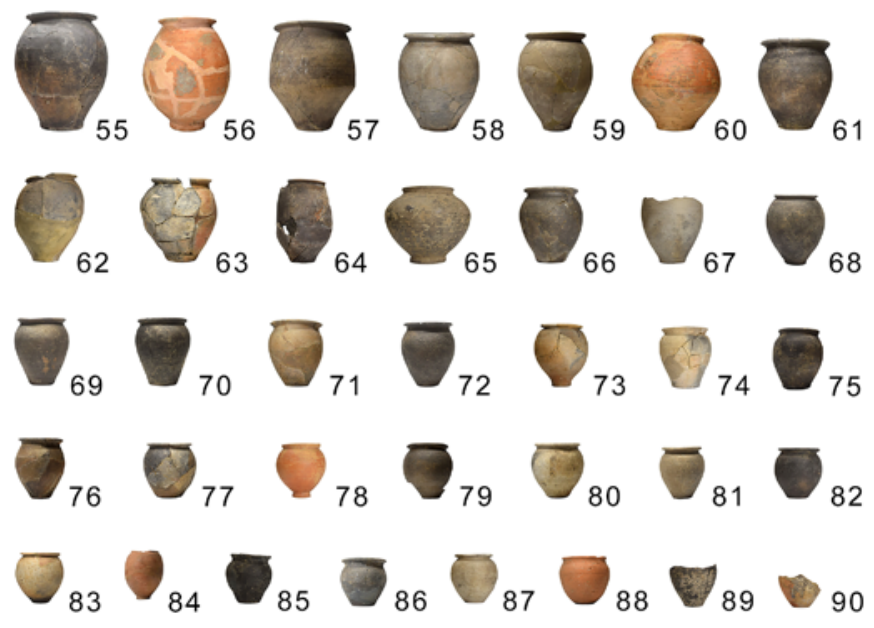

$$
25 \mathrm{~cm}
$$

Fig. 4. Generated models of the pottery set with calculated volumes.

Group No. 1: Jugs and pitchers. Deposited in the Archaeological museum SNM. Models by Z. Porubčanová.

Obr. 4. Vygenerované modely keramického souboru s vypočtenými absolutními objemy. Skupina č. 1: Džbány a konvice. Uloženo v Archeologickém múzeu SNM. Modely Z. Porubčanová.

Fig. 7. Pottery set with calculated volumes. Group No. 3: Convex vessels. Deposited in the Archaeological museum SNM. Photo by A. Szabová.

Obr. 7. Keramický soubor s vypočtenými absolutními objemy. Skupina č. 3: Baňaté nádoby. Uloženo v Archeologickém múzeu SNM. Foto A. Szabová. 

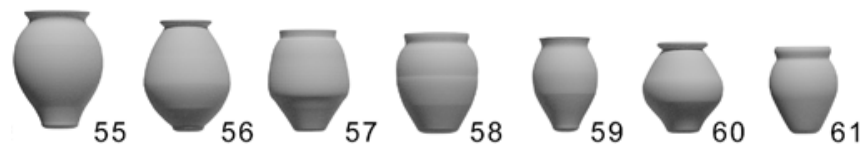

$\square_{62}$

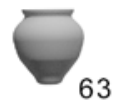

54
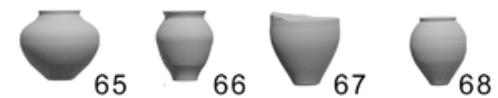

$\underbrace{}_{69}$
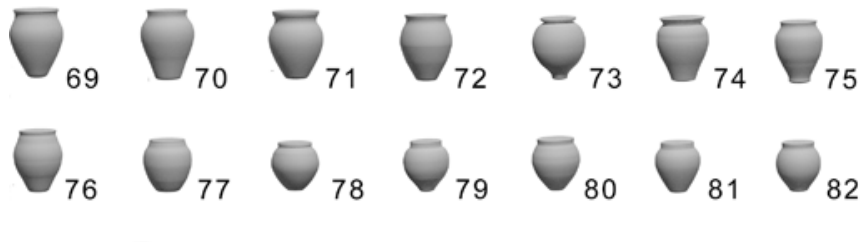

83 84 85 86
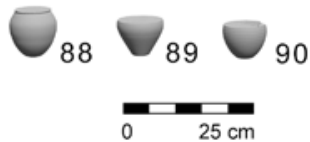

Fig. 8. Generated models of the pottery set with calculated volumes. Group No. 3: Convex vessels. Deposited in the Archaeological museum SNM. Models by Z. Porubčanová.

Obr. 8. Vygenerované modely keramického souboru s vypočtenými absolutními objemy. Skupina č. 3: Baňaté nádoby. Uloženo v Archeologickém múzeu SNM. Modely Z. Porubčanová.
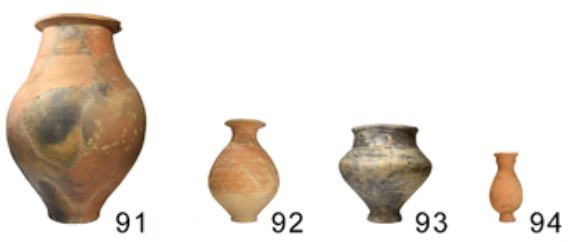

95

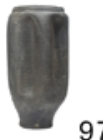

97
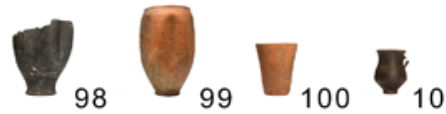

102

Fig. 9. Pottery set with calculated volumes. Group No. 4: Others - vases, amphora-shape vessels, cups. Deposited in the Archaeological museum SNM. Photo by A. Szabová.

Obr. 9. Keramický soubor s vypočtenými absolutními objemy. Skupina č. 4: Ostatní (vázy, amfory a poháry). Uloženo v Archeologickém múzeu SNM. Foto A. Szabová.
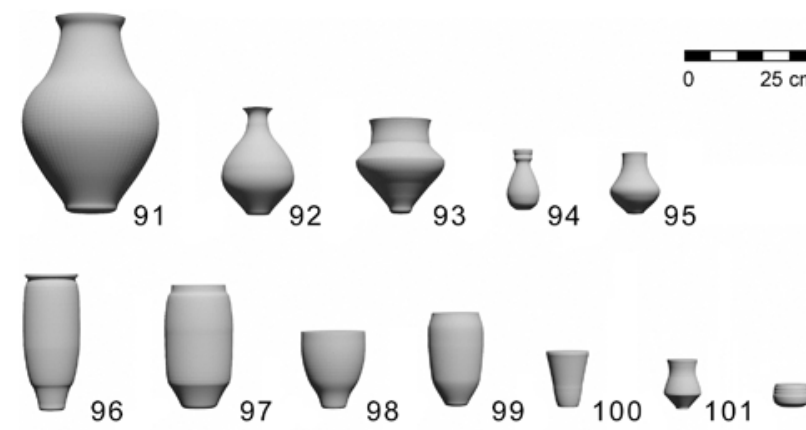

Fig. 10. Generated models of the pottery set with calculated volumes. Group No. 4: Others - vases, amphora-shape vessels, cups. Deposited in the Archaeological museum SNM. Models by Z. Porubčanová.

Obr. 10. Vygenerované modely keramického souboru s vypočtenými absolutními objemy. Skupina č. 4: Ostatní (vázy, amfory a poháry). Uloženo v Archeologickém múzeu SNM. Modely Z. Porubčanová.
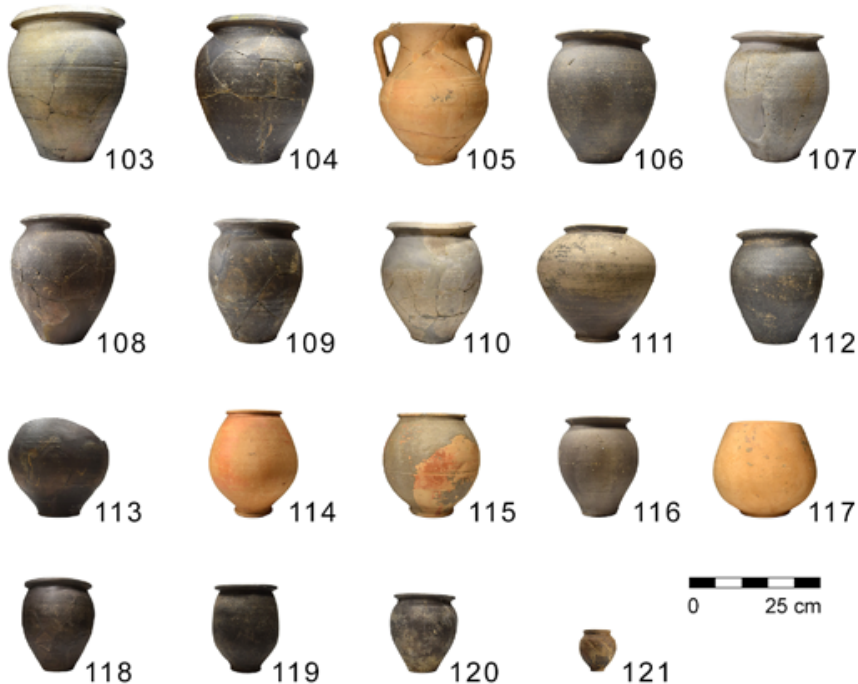

Fig. 11. Pottery set with calculated volumes. Group No. 5: Urns. Deposited in the Archaeological museum SNM. Photo by A. Szabová.

Obr. 11. Keramický soubor s vypočtenými absolutními objemy. Skupina č. 5: Urny. Uloženo v Archeologickém múzeu SNM. Foto: A. Szabová.
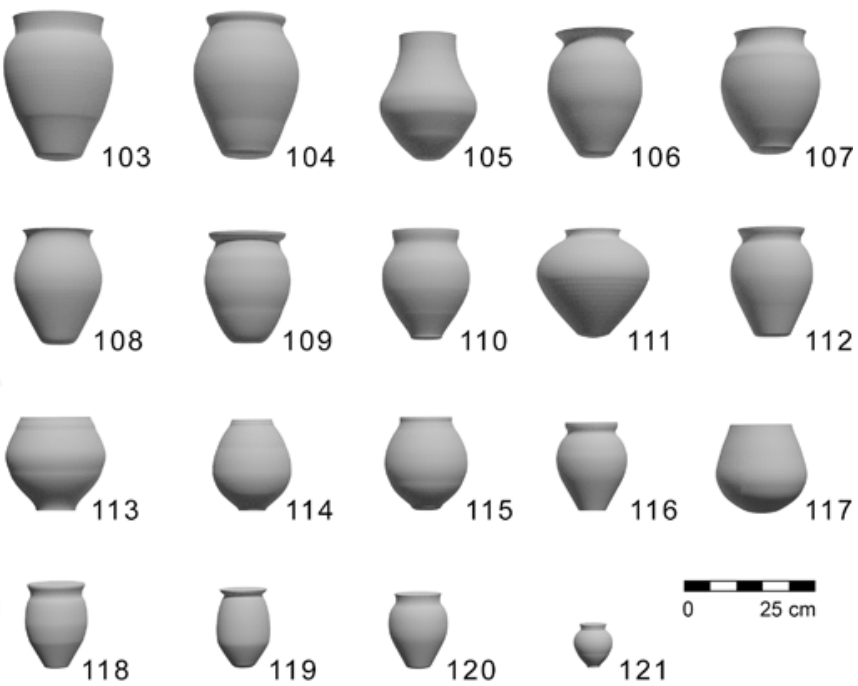

Fig. 12. Generated models of the pottery set with calculated volumes. Group No. 5: Urns. Deposited in the Archaeological museum SNM. Models by Z. Porubčanová.

Obr. 12. Vygenerované modely keramického souboru s vypočtenými absolutními objemy. Skupina č. 5: Urny. Uloženo vArcheologickém múzeu SNM. Modely Z. Porubčanová.

The fourth group (Fig. 9, 10) was the most diverse one due to the lack of representatives, and, therefore, has the lowest informative value. This had to be taken into consideration in the following steps (particularly in statistics). The first part of this group was formed by five vases and amphora-shape vessels with a height range between 10.7-33.5 cm, a mouth diameter of $6.21-15.22 \mathrm{~cm}$ and a base diameter of $2.9-8.89 \mathrm{~cm}$. The second part was formed by various types of cups (seven), although four were folded beakers (ger. der Faltenbecher). The height ranges between $4.1-24 \mathrm{~cm}$, the mouth diameter between $5.63-10.75 \mathrm{~cm}$ and the base diameter between $2.9-6.5 \mathrm{~cm}$. The calculated volumes of the folded beakers are slightly higher than the real ones because of the uneven folding of the cup wall, which could not be 
accurately measured. The last (fifth) group (Fig. 11, 12) was comprised of urns with a height between 4.9-29 $\mathrm{cm}$, a maximum bulge of 6.5-15 cm, a mouth diameter of 5.85-19.5 cm and a base diameter of 3.25-10.8 cm. Even though most of the urns had a convex shape similar to the vessels in the third group, we decided to create an individual category for them because of their different function in the grave inventory. The wall thickness was also important for the volume calculations and oscillated mostly between $0.3-1.0 \mathrm{~cm}$, depending on the type of vessel and the body area.

The total number of vessels identified from the necropolis is currently 409, although most of them are obviously preserved in fragments. For potential structural coherence identification, we worked not only with the vessel volumes but also with the shape groups. For this reason, when working with the hypotheses that dealt with the shape, we used the whole set of pottery (including fragments), not only the measurable part. Concerning the funerary practices, primary variables such as the burial type (inhumation/cremation), grave type, gender or age of the person buried and the chronological interval and location of the artefact in the grave were chosen for testing. Gender and age identification comes from the two individual anthropological studies (Pichlerová, Stloukal 1977, 1981). In addition to elementary questions such as the average volume of the different shapes, the amount of pottery in the graves etc., we created several question sections where the null and the alternative hypothesis were formed in each section. The first category was defined by the question of whether the volumes statistically significantly differ in the various shape groups. Because the urns are, unlike any other ceramic vessels, the functional element of the burial practice (not the offering), they were treated separately first. Therefore, we asked if there was a significant difference in the urn volumes within the aforementioned variables (grave type, gender, age etc.).
The third section has already addressed all the shape groups; otherwise, it was the same as the last one and followed the volume differences in the various grave categories. The next category formed a different type of question - whether a correlation between the volume and the other variables exists (e.g., Is there a correlation between the vessel volume and the age of the deceased?). The final three sections used the whole set of pottery (not only the part with the calculated volumes). The fifth category examined the significant differences in the frequency of the vessels within the referred variables. The following category also traced the differences within the variables but instead of frequency, we worked with the shape spectrum. The last analysis attempted to find a correlation between the shape and the other variables. By creating the two question types (difference/ correlation), we ensured partial mutual control of the results.

\section{Methods}

Three-dimensional models of each vessel from the collection were created in Blender v2.79 open-source software. The same software was also used to calculate the approximate absolute volume of the vessels. For the 3D reconstruction, a drawing and photo documentation of the vessel profile and its dimensions (height, throat diameter, maximum bulge, base diameter and thickness of the walls) was needed. In most cases, drawing documentation with a relevant scale was sufficient for the model generation. Still, the dimensions acquired by documentation can slightly differ from the real dimensions, especially the thickness of the vessel, which is often not constant. The lower part of the vessel usually has thicker walls than the rest of it. The wall thickness of the different parts of the vessel was measured where possible (e.g., on bowls, plates and other wider vessels). However, this could not be done with some shapes with a narrower throat
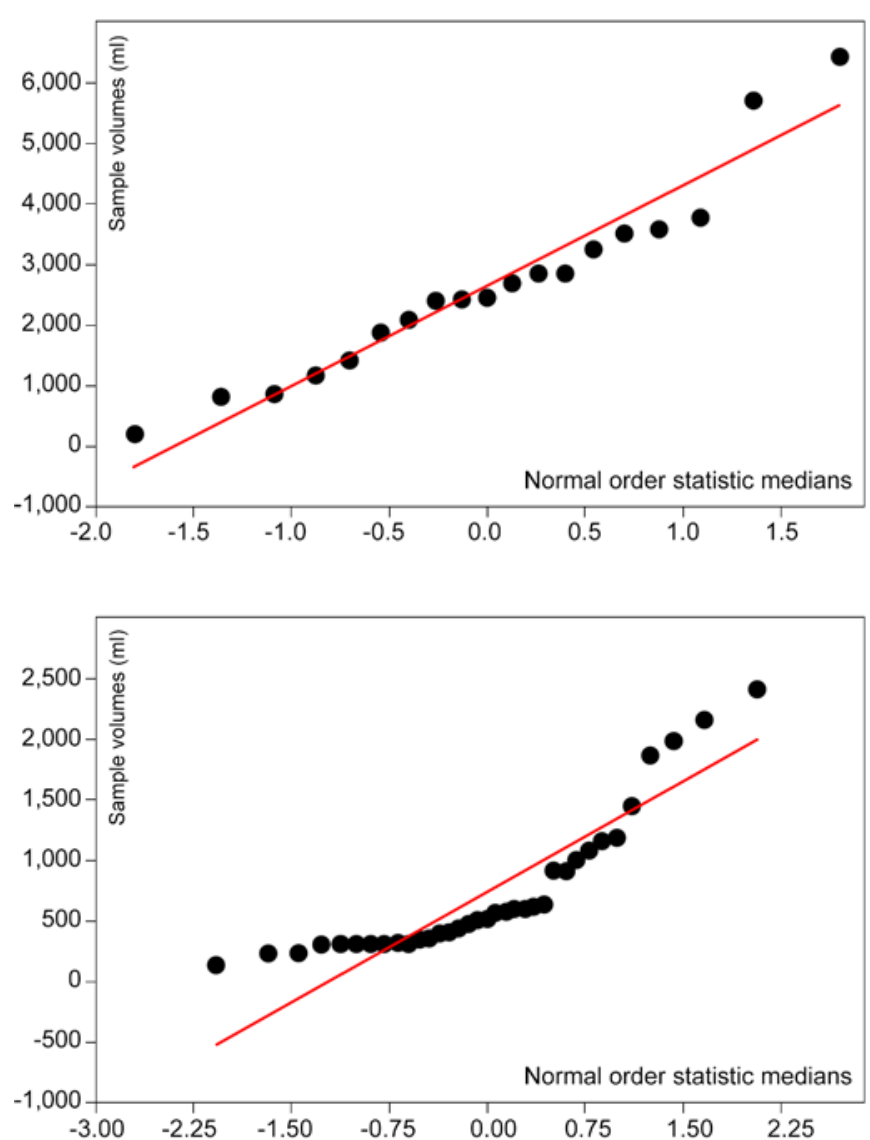

Tests for normal distribution

\begin{tabular}{|l|l|}
\hline & All \\
\hline $\mathrm{N}$ & 19 \\
\hline Shapiro-Wilk W & 0.9368 \\
\hline $\mathrm{p}$ (nomal) & 0.2312 \\
\hline Anderson-Darling A & 0.4327 \\
\hline $\mathrm{p}$ (normal) & 0.2723 \\
\hline $\mathrm{p}$ (Monte Carlo) & 0.2822 \\
\hline Jarque-Bera JB & 2.184 \\
\hline $\mathrm{p}$ (nomal) & 0.3356 \\
\hline $\mathrm{p}$ (Monte Carlo) & 0.1089 \\
\hline
\end{tabular}

Tests for normal distribution

\begin{tabular}{|l|l|}
\hline & All \\
\hline $\mathrm{N}$ & 36 \\
\hline Shapiro-Wilk W & 0.7955 \\
\hline $\mathrm{p}$ (normal) & $1.67 \mathrm{E}-05$ \\
\hline Anderson-Darling A & 2.676 \\
\hline $\mathrm{p}$ (normal) & $6.813 \mathrm{E}-07$ \\
\hline $\mathrm{p}$ (Monte Carlo) & 0.0001 \\
\hline Jarque-Bera JB & 14.78 \\
\hline $\mathrm{p}$ (normal) & 0.0006186 \\
\hline $\mathrm{p}$ (Monte Carlo) & 0.0053 \\
\hline
\end{tabular}

Graph 1. Normality of data distribution presented by the norma probability plots on the left and by the tests for normal distribution on the right. The normal data distribution of volumes in the fifth shape group (urns) in the upper part and the abnormal distribution of volumes in the third shape group (convex vessels) in the lower part.

Graf 1. Normalita datové distribuce, která je nalevo zobrazena na normálních pravděpodobnostních grafech a napravo pomocí testů normálního rozdělení. Vhorní části jsou prezentovány objemy 5. tvarové skupiny (uren), které mají normální distribuci dat, a ve spodní části jsou objemy 3. tvarové skupiny (baňatých nádob), které nemají normální distribuci dat. 
(e.g., amphora-shaped vessels or jugs). Therefore, there could be a minor difference between the real and the calculated volumes.

First, the shape of the inner profile of each vessel was created using Bezier's curves. Afterwards, the inner body of the vessel was created by function "spin”, where the inner profile spun $360^{\circ}$ around the Z-axis. Bezier's curves were transformed to vertices for better manipulation with the shape of the model. Because of the vertices, the individual mesh sections of the model could be adjusted to the shape of the real vessel. Before calculating the absolute volume, the model needed to be closed with polygons at the top and bottom. Finally, the normals were calculated to correct vertices, which could deform the morphology of the model. The program could then calculate the absolute volume of the vessel in $\mathrm{cm}^{3} \mathrm{or} \mathrm{m}^{3}$, which was then converted to $\mathrm{ml}$ or 1 . This way of estimating vessel volumes in Blender was inspired by Köster's paper $(2015,1-8)$. A similar method was used in the study by Emmitt (2020, 4-6), where it also proved to be effective. The technique for calculating vessel volume from profile drawings was also discussed by Senior and Birnie (1995, 319-334).

The veracity of each hypothesis was then validated or disproved by univariate tests in PAST 3 open-source software for scientific data analysis (Hammer et al. 2001, 2-3). The testing is basically a comparison of the observations that are predicted in the hypothesis and the observations of the evidence in reality (Demján 2020). The first step was to create the null hypothesis, which states that observations are just a product of coincidence (Neustupný 1973, 192). For example, the prediction that there is no statistically significant difference between the urn volume of the adult and the child. We could assume that the alternative hypothesis we defined (e.g., there is a statistically significant difference between the urn volume of the adult and the child) was valid if the null hypothesis were disproved (Otárola-Castillo, Torquato 2018, 437). For choosing the adequate type of statistical analysis, it was important to first check the data distribution (Graph 1), which could be observed on several plots (the normal probability plot in particular) or by using tests for normal distribution; e.g., the Shapiro-Wilk test (Weber 1997, 206-207). According to the results of each data set, parametric or non-parametric tests were used to validate the hypothesis (Neustupný 1973, 228).

From the two-sample parametric tests, the T-test for equal means was applied and the F-test for equal variances was less frequently used. From the non-parametric tests, the Mann-Whitney $U$ test for equal medians was applied and Mood's median and the Kolmogorov-Smirnov test for equal distributions was less frequently used (Weber 1997, 206-209). The level of significance (Drennan 2010, 29-31) was 5\% in all cases. From several sample tests, on the one hand, One-way ANOVA and Tukey's range test for equal means were used, and on the other hand, Mann-Whitney pairwise and Kruskal-Wallis were used (Weber 1997, 206-209). For testing the presence of the association between the variables, Chi-squared and Fisher's exact test (Weber 1997, 208) were applied. However, the expected frequencies using the totals of the variables had to be calculated beforehand (Neustupný 1973, 193).

Data visualisation also formed (besides the testing of individual hypotheses) a significant part of the statistical analysis. For this purpose, a histogram (Graph 8) was often used where both the frequency and our data distribution combined with normal distribution (expressed as a Gaussian curve) are visible. Box plot (Graph 4) expressing median, 25th and 75th percentile, standard error and deviation, outliers or the maximum and minimum digits, were also effective (Drennan 2010, 11-13, 37-41). The comparison of our data distribution to normal distribution can also be seen (except the histogram) in the normal probability plot, which also shows a correlation coefficient for every variable (Graph 1). Nonetheless, various other graphic visualisations were also useful (Graph 2, 3, 5, 7-10).

\section{Results}

As mentioned above, 121 3D vessel models were created. Eight vessels were preserved in the fragmented condition. Therefore, the calculation of the absolute volumes was impossible. In these cases, the program could only calculate the minimum volumes. Half of these belong to the category of the convex vessels, two to the jugs, one to the urns and one to the cups. However, excluding these vessels (as well as the folded beakers) made no significant difference in the results, so we decided to keep the collection complete on account of the higher variability.

The highest absolute volume of all the models measured in the jugs' group was 7,208 $\mathrm{ml}$. The lowest absolute volume of the jugs was $617 \mathrm{ml}$, which is the highest amongst the lowest volumes of all vessels. This category also had the second-highest average absolute volume of all the shape groups with $2,450 \mathrm{ml}$. First were the urns with an average absolute volume of 2,596 ml. This group also had the second-highest absolute volume with $6,427 \mathrm{ml}$. The jugs and the urns had higher volumes than other categories in general. The lowest absolute volumes were measured within the bowls and plates group and the convex vessels. These categories also had the lowest average absolute and maximum absolute volumes. This means a $656 \mathrm{ml}$ average volume for bowls and plates and $737 \mathrm{ml}$ for convex vessels. The highest volume for bowls and plates was 3,513 $\mathrm{ml}$ and 2,384 $\mathrm{ml}$ for convex vessels. The lowest absolute volume (about $71 \mathrm{ml}$ ) was measured in the bowls and plates group. In the fourth group, the lowest volume was $89 \mathrm{ml}$. The shape variety of this group is visible on the volume calculation results. The highest absolute volume in this category was $6,345 \mathrm{ml}$, the third-highest of all the volumes. The average absolute volume was $1,116 \mathrm{ml}$. Finally, the average volume of all modelled vessels was $1,511 \mathrm{ml}$.

The regular frequency of the vessels in the grave ranged between 0 and 4 . There were no vessels in 84 graves, one in 63 graves, two in 47 graves, three in 22 graves and four in 13 graves to be specific. The higher amount of the vessels is less common ( $7 \times 5$ pieces, $5 \times 6$ or 7 pieces, $4 \times 8$ pieces and only $1 \times 9$ pieces). Within the shape variability, the most frequent were jugs (or pitchers) with 116, then bowls (or plates) with 99, and a convex

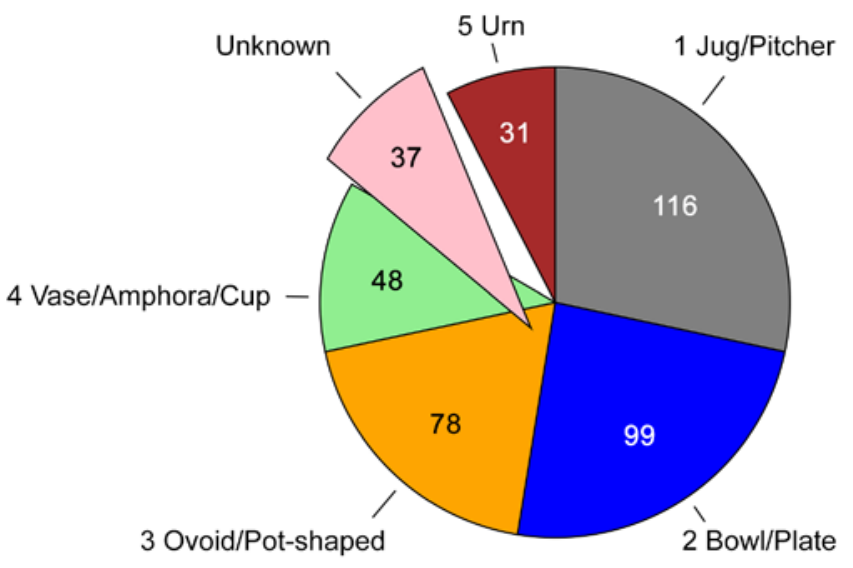

Graph 2. Pie chart picturing the total numbers of various shapes of the vessels within our data set (including fragments).

Graf 2. Koláčový graf zobrazující celkové počty různých tvarů nádob vnašem datovém souboru (včetně fragmentů). 


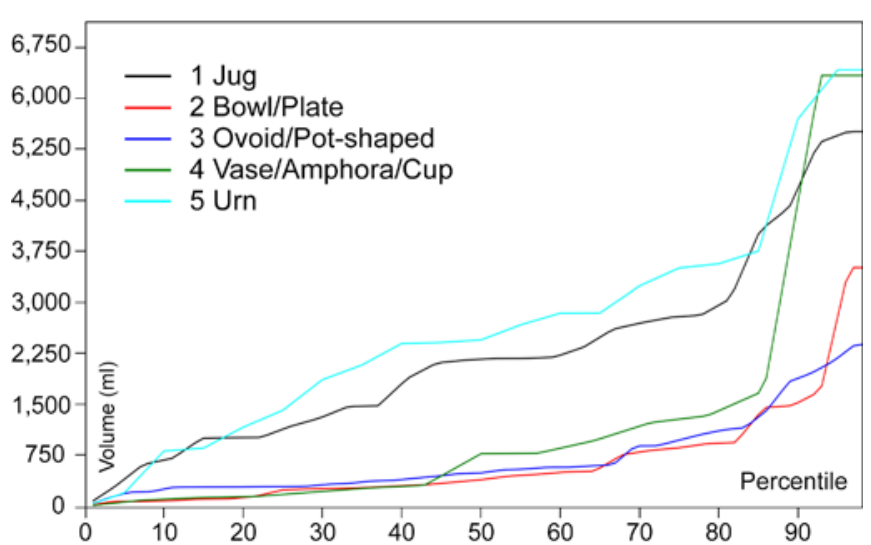

Graph 3. Percentile graph picturing the vessel volume distribution in the different shape groups.

Graf 3. Percentilový graf zobrazující distribuci objemů nádob v různých tvarových skupinách.

vessel with 78 was the third most frequent. There were 31 vessels identified as urns with 48 vessels in the "other" category (vases, amphora-shaped vessels and cups). Thirty-seven of the pottery fragments were unidentifiable (Graph 2).

Most of the data sets used did not have normal distribution (Shapiro-Wilk, p[normal for jugs $=0.03588$; bowls $=5.655 \times 10^{-6}$; convex vessels $=1.67 \times 10^{-5}$; other $=5.872 \times 10^{-5}$; urns $=0.2312$ ) and many of them contained a couple of outliers. For this reason, we used the non-parametric tests more often than the parametric ones throughout the analysis. First, we attempted to detect significant differences or similarities between the volumes in the various shape categories. As a result, we found that there is no significant difference between the volumes of jugs and urns (Mann-Whitney, p[same med.] = 0.30649). These two categories also had the highest mean volume (Graph 3). Other statistically significant similarities could be observed between bowls/plates and convex vessels (Mann-Whitney, p[same med.] =1.8672). On the one hand, the convex vessels were generally higher but on the other hand, the bowls were mostly wider, which caused their parallel volume range. The fourth category (vases, cups etc.) is statistically similar to bowls (Mann-Whitney, p[same med.] = 0.50659) and also to convex vessels (Mann-Whitney, p[same med. $]=0.79857)$. However, in this case, we had to consider the

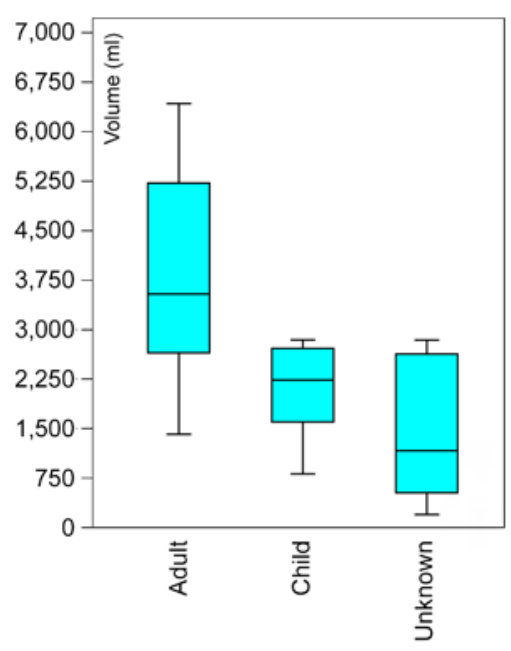

Graph 4. Box plot picturing the urn volume distribution within the different age groups.

Graf 4. Krabicový diagram zobrazující distribuci objemů uren vrüzných věkových skupinách. large variability and the low number of individuals. The probability of different results after the increase of the artefacts amount is rather high.

The set of urn volumes had a normal distribution (Graph 1), so in this case, we used the parametric tests (T-test, F-test). We could not search for the differences in the case of gender because there were too many unidentifiable individuals although the age analysis provided interesting results. The adult urn volumes were significantly different from the children's ( $t$-test, $p$ [same mean $]=0.04054$ ) and the unknown's as well ( $\mathrm{t}$-test, $\mathrm{p}$ [same mean $]=0.019724)$. However, children's and unknown's urns had statistically similar volumes (t-test, $\mathrm{p}$ [same mean] $=0.2987$ ). The volumes of the adult urns had a significantly higher mean value (Graph 4). No difference was recognised within the time intervals ( $\mathrm{t}$-test, $\mathrm{p}$ [same mean] $=0.10677-0.78207$ ). The same applies to the vessel locations as the majority of the urns were located in the middle part of the grave (other locations occurred only sporadically).

After the analysis of the whole set of calculated volumes (urns + offerings), the higher mean of the vessel volumes in the cremation graves was noticeable (Mann-Whitney, $\mathrm{p}$ [same med.] = 0.020481 ) although after excluding the urns, there was no significant difference (Mann-Whitney, p[same med.] $=0.20797$ ) Within the individual shape groups, only the fourth group had considerably higher volumes in the cremation than in the inhumation graves (Mood median, $\mathrm{p}$ [same med.] $=0.0083153$; Kolmogorov-Smirnov, $\mathrm{p}$ [same dist.] $=0.029391$ ). Among the grave types, there was a difference documented only between the simple pit inhumation graves and the urn graves - the urn graves had a higher mean volume (Mann-Whitney pairwise, $\mathrm{p}=0.03803$ ). No difference was registered between the genders (Mann-Whitney pairwise, $\mathrm{p}=0.6156-0.9123$ ). Adult graves had a mildly but not significantly higher mean volume (Graph 5 ) than the children's (Mann-Whitney pairwise, $\mathrm{p}=0.1001$ ) and unspecified graves (Mann-Whitney pairwise, $\mathrm{p}=0.6355$ ). The jugs ( $\mathrm{t}$-test, $\mathrm{p}$ [same mean] $=0.03541$ ) and the others (Mann-Whitney, $\mathrm{p}$ [same med.] $=0.095836)$ had a particularly higher mean volume in the adult graves. On the time scale, there was no significant difference between most of the intervals (Graph 6).

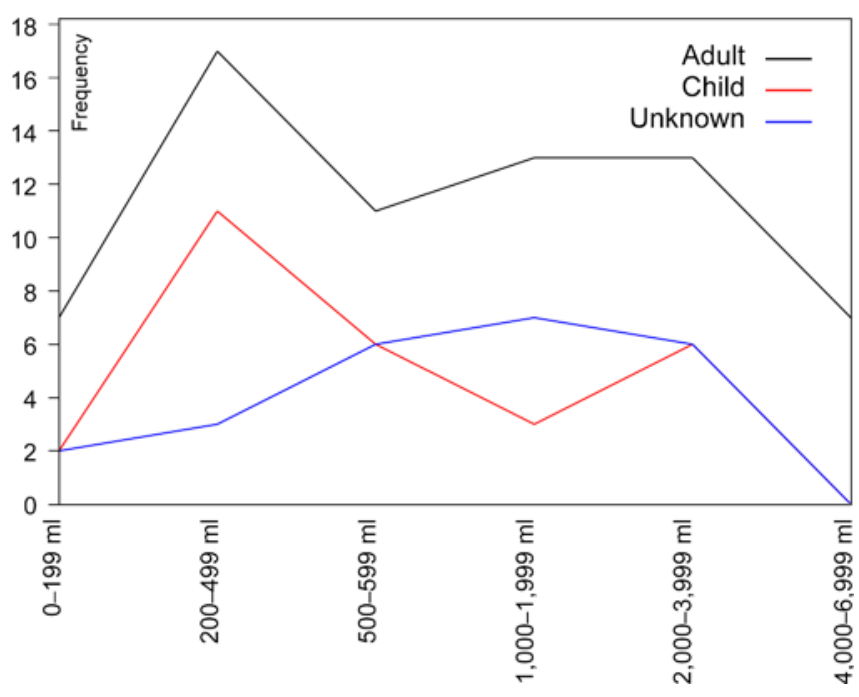

Graph 5. Line chart picturing the vessel volume distribution in the different age groups.

Graf 5. Liniový graf zobrazující distribuci objemů nádob v různých věkových skupinách. 


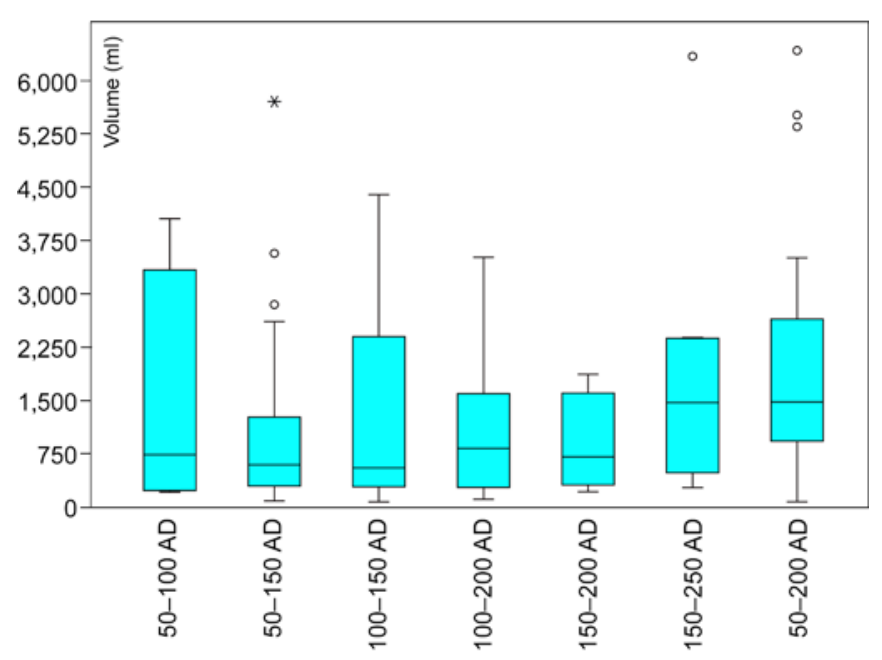

Graph 6. Box plot picturing the vessel volume distribution within the various time intervals (+ outliers).

Graf 6. Krabicový diagram zobrazující distribuci objemů nádob v různých časových intervalech (+ extrémní hodnoty).
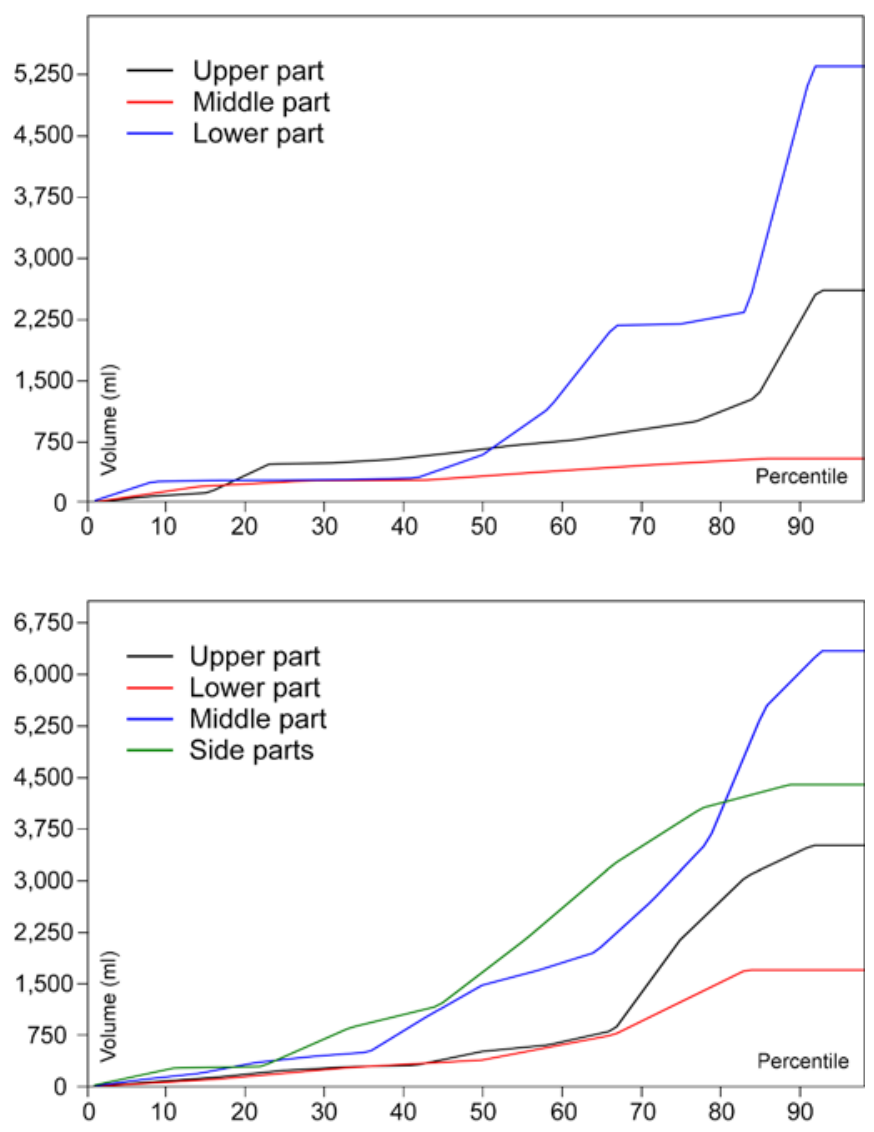

Graph 7 a, b. Percentile graph picturing the vessel volume distribution in the different parts of inhumation (a) and cremation (b) graves.

Graf $\mathbf{7}$ a, b. Percentilový graf zobrazující distribuci objemů nádob v různých částech kostrového (a) a kremačního (b) hrobu.

Only the wide interval of 50-200 AD differed (had a higher mean value) from three of the others (Mann-Whitney pairwise, $\mathrm{p}$ for $50-150 \mathrm{AD}=0.00991$; for $100-150 \mathrm{AD}=0.0318$; for $100-200 \mathrm{AD}=0.02813)$. In the inhumation graves, there was no vessel located in the right-middle part of the grave. The most

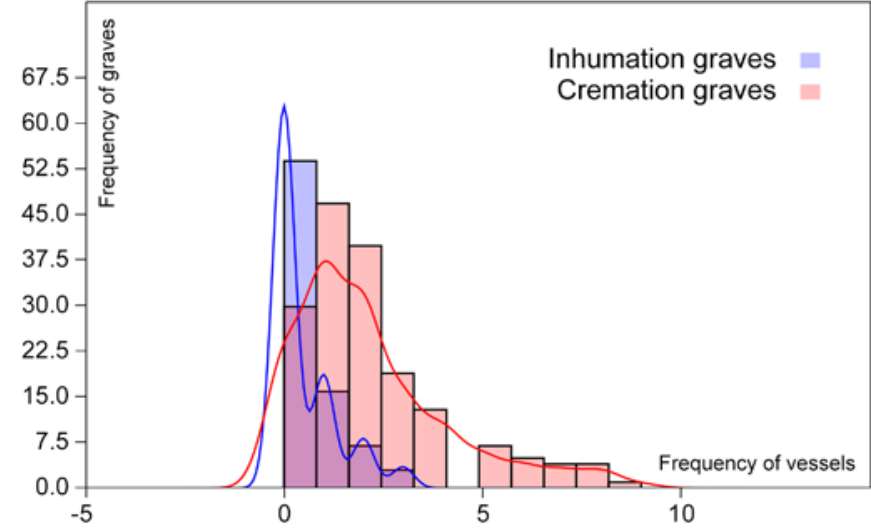

Graph 8. Histogram picturing the distribution of ceramic vessels in the inhumation and in the cremation graves.

Graf 8. Histogram zobrazující distribuci keramických nádob v kostrových a kremačních hrobech.

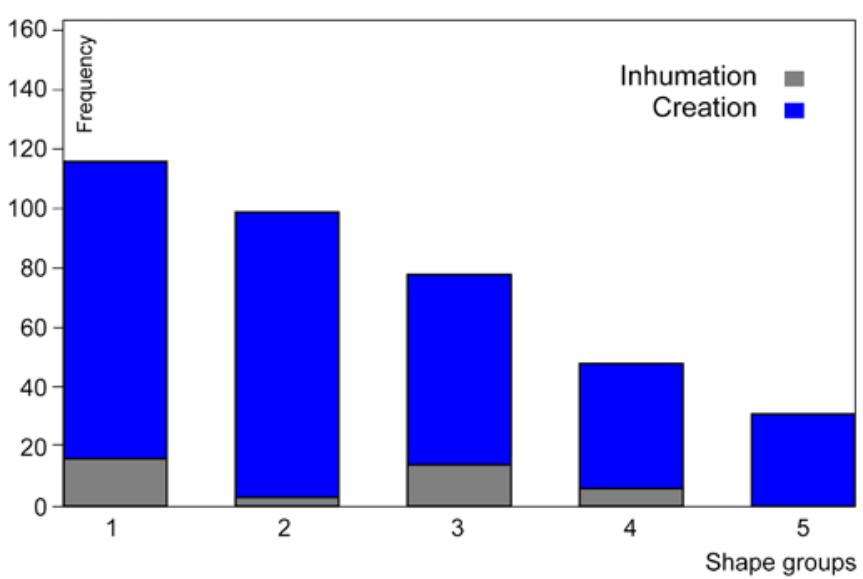

Graph 9. Stacked bar graph picturing the shape distribution of ceramic vessels in the inhumation and cremation graves.

Graf 9. Skládaný sloupcový graf zobrazující distribuci tvarů keramických nádob v kostrových a kremačních hrobech.

frequently used locations were the lower-middle and upper-right parts (Graph 7a). The only significant difference appeared between the grave centre and the left part. The vessels in the centre had a higher mean volume (Mann-Whitney, p[same med.] $=0.04157)$. The majority of the vessels in the cremation graves (except the urns) were located in the lower part (Graph 7b) with the least in the left part of the grave. No significant difference was found there (Mann-Whitney pairwise, $p=0.1449-0.7018$ ).

No correlation between the volumes and the other variables was proven (Chi-squared, p[no assoc.] $=0.10869-0.2447$ ). Unfortunately, three of the variables (gender, time and location) could not be tested, even after the partial unification of the options, because of the expected low frequencies. As previously mentioned, in the last three analyses we engaged the whole data set of 409 vessels and fragments. In the cremation graves, there were significantly higher amounts of vessels (Graph 8) than in the inhumation ones (Mann-Whitney, $\mathrm{p}$ [same med.] = $\left.3.1108 \times 10^{-15}\right)$. There was a difference between the simple pit inhumation graves and almost all types of cremation (Mann-Whitney pairwise, $\mathrm{p}$ for simple pit $=2.597 \times 10^{-5} ; \mathrm{p}$ for graves without the cremation residuals $=0.0001093 ; \mathrm{p}$ for graves with the 
cremation residuals $=1.578 \times 10^{-12} ; \mathrm{p}$ for urn graves $\left.=7.548 \times 10^{-9}\right)$. All the cremation types had a higher number of artefacts. Busta and graves with cremation residuals were distinguished within the cremation, which had a higher number of finds (Tukey's pairwise, $\mathrm{p}=0.03179)$.

The graves with an unidentified gender had a higher mean value than males (Mann-Whitney pairwise, $\mathrm{p}=0.001316$ ) and according to some of the tests (e.g., Mann-Whitney pairwise, $p=0.03186$ ), also females. However, the difference was lower for the females. In terms of the age of the deceased, the unidentifiable individuals were also the most numerous (Mann-Whitney pairwise, $\mathrm{p}$ for adults $=0.006016$; $\mathrm{p}$ for children $=0.02595)$. In terms of chronology, the interval of 50-200 AD again differed (had a lower mean value) from many others (Mann-Whitney pairwise, $\mathrm{p}$ for $50-150 \mathrm{AD}=5.912 \times 10^{-6}$; $\mathrm{p}$ for $100-150 \mathrm{AD}=3.708 \times 10^{-8}$; $\mathrm{p}$ for $100-200 \mathrm{AD}=5.714 \times 10^{-8}$; p for $150-250 \mathrm{AD}=0.0005247$ ). However much fewer of the graves belonged to this time interval.

The shape variation of the whole data set showed no significant difference (Mann-Whitney, $\mathrm{p}$ [same med.] $=0.54676$ ) between the inhumation and cremation burials (Graph 9). Within the grave types, only the urn graves differed (Mann-Whitney pairwise, $p=5.69 \times 10^{-8}-1.289 \times 10^{-6}$ ) because of the obvious fact that there was a high number of urns there (Graph 10). Analysis of the gender and age showed no statistically significant difference (Mann-Whitney pairwise, $\mathrm{p}$ for gender $=0.4329-0.6623$; $\mathrm{p}$ for age $=0.1143-0.5177)$. In terms of chronology, most of the time intervals showed similar results (Mann-Whitney pairwise, $p=0.06187-0.9808)$. However, there was a difference of the interval 150-200 AD from all of the others (Mann-Whitney pairwise, $p=0.004872-0.01507)$. Testing of the vessel location in the cremation graves showed similar results in all parts of the grave (only the urns were mostly located in the centre as mentioned above). In the inhumation graves, the right part differed (Mann-Whitney, p[same med.] $=0.018881$ ) from the left (this was caused by the fact that the jugs dominated the right). The last analysis revealed a correlation of medium intensity (Contingency $\mathrm{C}=0.20114$ ) between the vessel shape and the type of burial (Chisquared, $\mathrm{p}$ [no assoc. $]=0.00347337$ ), as well as a high intensity correlation (Contingency $\mathrm{C}=0.62922$ ) within the grave type variable (Chi-squared, $\mathrm{p}$ [no assoc. $\left.]=1.8625 \times 10^{-27}\right)$. A correlation

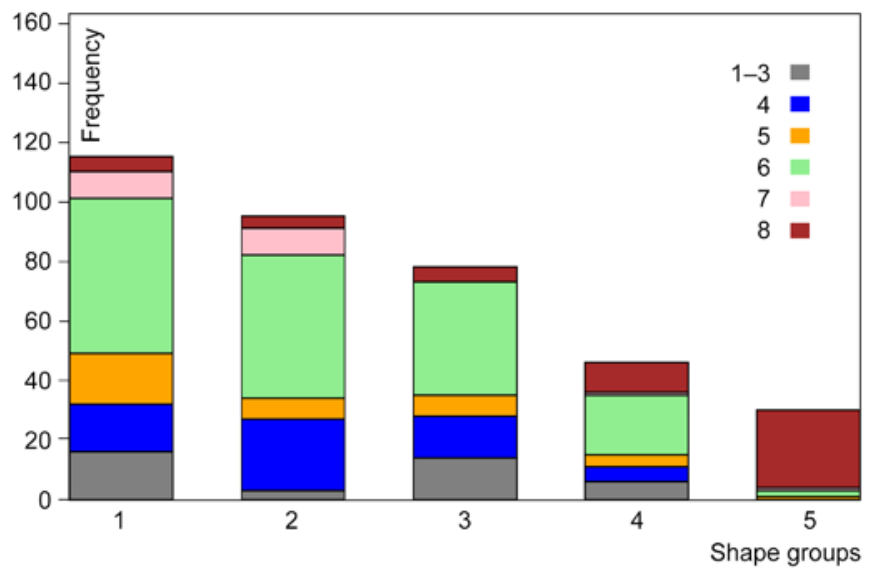

Graph 10. Stacked bar graph picturing the shape distribution of ceramic vessels in the different grave types. 1 - simple pit, 2 - brick tomb, 3 - others (mostly alcoveor shaft graves).

Graf 10. Skládaný sloupcový graf zobrazující distribuci tvarů keramických nádob v různých typech hrobů. 1 - jednoduchý jámový hrob; 2 - cihlová hrobka; 3 - další (především výklenkové či šachtové hroby). between the shape and location as well as the shape and gender could not be tested (because of the expected low frequencies). A middle intense correlation (Contingency $\mathrm{C}=0.32077$ ) was proven between the shape and the chronology (Chi-squared, $\mathrm{p}[$ no assoc. $]=0.0031372)$ and none within the age of the deceased (Chi-squared, p[no assoc. $]=0.30752$ ).

\section{Interpretation and discussion}

The standard number of pottery in graves in necropolis II in Gerulata was 0-4. On average, the cremation burials had more vessels than the inhumation burials, which also corresponds with other items from the grave inventory. This could be because the cremated population was the wealthier one, as stated in other studies (Krekovič 2011, 102). The highest number (9 pieces) of vessels was found in grave No. 95. However, besides the vessels, there were only two other items present - a ceramic lamp and a wooden box with iron fittings (Pichlerová 1981, 145-146). There were between two and six other artefacts in the graves rich with pottery. Nonetheless, we could identify some of the graves (in the context of this necropolis) as relatively wealthy. For example, in female grave No. 1, two ceramic lamps, a bone pin, a bronze tweezer, three bronze circular rivets, a bronze coin from the reign of Emperor Domitian (81-96 AD), a small glass vase, an iron knife, a wooden box with iron fittings, iron rivets and nails, and the bones of a dog and a small ruminant (goat/ sheep) were found. The pottery spectrum consisted of two jugs, a plate, an ovoid vessel, a terra sigillata bowl (Drag. 33) and fragments of four other unidentifiable vessels (Pichlerová 1981, 83-85; Gabler, Pichlerová 1996, 85).

Various combinations of jugs, bowls, plates and convex vessels were the most common. The analysis showed the use of larger vessels (particularly jugs and urns) in the graves of adult individuals. This was already indicated by the study of the urn shape indexes by Professor Krekovič, who recognised the possibility of correlation between the urn size and the age and gender of the person buried (Krekovič 2014, 816). Our analysis confirmed this between the age and the urn size and showed the same correlation in the case of jugs. Unfortunately, the coherence between vessel size and the gender of the deceased was not confirmed, although that was probably caused by the low number of gender-identified graves in our data set. The parametric tests also discovered significant parallels between the volumes of children's urns and the urns of the unidentifiable individuals. This could indicate that a certain amount of the unidentified deceased might be children or (according to the theory mentioned above) women. Another argument for the possibility of unidentified graves being partially children's graves is that these graves contained a significantly higher number of vessels in comparison with the graves of adult men and women.

A volume similarity between certain shapes such as jugs, urns, bowls and convex vessels is, within a limited range of provincial pottery, typical for the area and time period and is an understandable result. We could have obtained a more diverse outcome if there was a higher number of artefacts in the fourth shape group. The analysis also showed the larger vessel volumes in the cremation than in the inhumation burials, which was mainly caused by the presence of the urns and by the higher variability of the pottery in the cremation graves. This also transferred to the correlation between vessel shape and the type of burial (and grave type). Within the chronology differences, we found no significant changes in most of the time intervals. Only a wide interval of 50-200 AD had a higher vessel volume than others, but also the lowest amount of the pottery. Next, the interval 150-200 AD had a different shape variety than the others. 
Unfortunately, both these results were caused by the low number of individuals in those intervals and do not indicate any chronological changes in the pottery spectrum. In the inhumation graves, vessels were mostly cumulated by the feet or next to the skull of the buried, which were standard locations in many Pannonian cemeteries. In the cremation graves, the central area prevailed in the case of urns and the lower grave part in the case of offerings. However, a considerable amount of the fragmentarily preserved vessels were concentrated in more than one grave part.

\section{Conclusion}

A combination of several multidisciplinary methods (3D model generation, volume calculation, application of statistical analysis) helped us to detect certain indications of the structural coherence of the archaeological material (in this case, the pottery ware) and some of the burial factors in necropolis No. II in ancient Gerulata. Specifically, a relation between the size of the vessel and the age of the dead, or between the amount of the vessels and the burial type, was discovered. Naturally, we cannot generalise these results to all of the data in this particular collection (e.g., not all of the unidentified individuals with smaller urns must necessarily be children). Nevertheless, it could be partially valid (Neustupný 2007, 165-167).

Next to the validation of some of the hypotheses, the disproving of others was also important, for example, the negative evidence in the matter of changes in the volume or shape of the vessels during the time intervals with a sufficient quantity of subjects (apart from the intervals 50-200 and 150-200 AD). The application of different methods throughout the process of creating this study brought a more diverse perspective on the long known, but to date, mostly conventionally treated site.

\section{Acknowledgements}

We would like to express our gratitude to the staff of the Archaeological museum SNM, especially to the director PhDr. Juraj Bartík, Ph.D., for allowing the realisation of revision, then to PhDr. Klára Füryová, Mgr. Igor Choma, Sandra Csabiová, and particularly to Daniela Lacová, for their assistance during the documentation and archive investigation. Revision is part of the ongoing dissertation - A. Szabová: Funerary practices in Pannonia and the examination possibilities of protohistoric populations based on the example of cemeteries from ancient Gerulata. Supervisor: Mgr. Balázs Komoróczy, Ph.D. Institution: Department of Archaeology and Museology, Masaryk University. This study was created during the long-term cooperation of both authors with the Institute of Archaeology of the Czech Academy of Sciences, Brno. Our thanks go namely to Mgr. Balázs Komoróczy, Ph.D., and Mgr. Marek Vlach, Ph.D., for their guidance during the creation of this study. Last but not least, we would like to thank Mgr. Peter Tóth, PhD., for the introduction to the statistical analysis, and to MA. Joshua Emmitt, PhD., for the consultation on model generation.

\section{References}

Demján, P. 2020: Štatistická analýza v archeológii. In: You Tube [online]. 2. 4. 2020 [cit. 2021-01-11]. Available from: https://www.youtube.com/watch?v=kMoTy23eYaQ.

Drennan, R. D. 2010: Statistics for Archaeologists. A Commonsense Approach. Second edition. New York: Springer.

Emmitt, J. 2020: Formation and function: Middle Holocene pottery from Kom W, Fayum, Egypt. Quaternary International 555, 126-134. [cit. 2021-01-11] DOI: https://doi.org/10.1016/j.quaint.2019.09.032. Available from: https://www.sciencedirect.com/science/article/pii/ S1040618219307827?via\%3Dihub.
Gabler, D., Pichlerová, M. 1996: Terra sigillata von Gerulata. In: K. Kuzmová, J. Rajtár (eds.): Gerulata I. Nitra: Archeologický ústav Slovenskej akadémie vied v Nitre, 45-143.

Hammer, Ø., Harper, D. A. T., Ryan, P. D. 2001: PAST:

Paleontological statistics software package for education and data analysis. Palaeontologia Electronica 4(1), 1-9.

Hlavatá, J., Varsik, V. 2019: Sídlisko autochtónnej panónskej populácie v Rusovciach: Prvé výsledky archeobotanických analýz. In: Sedem kruhov Josefa Bujnu. Studia Historica Nitriensia 23, Supplementum 2. Nitra: Univerzita Konštantína Filozofa v Nitre, 427-448.

Hlavenková, L., Schmidtová, J., Zeman, T. 2015: Paleodemografia rímskej populácie Gerulaty v 1. až 4. storočí n. 1. Historická demografie 39(2), 137-179.

Köster, J. 2015: Calculate vessel volume with Blender. Academia [online] (C2021. 03-02-2015 [cit. 2021-01-11.]. Availlable from: https://www.academia.edu/11200820/Calculate_vessel_volume_ with_Blender.

Krekovič, E. 1992: Skelettgräber der älteren römischen Kaiserzeit im Licht der Funde aus Gerulata. Carnuntum Jahrbuch 1991, 71-79.

Krekovič, E. 1998: Römische Keramik aus Gerulata. Bratislava: Filozofická fakulta Univerzity Komenského v Bratislave.

Krekovič, E. 2011: Deti v Gerulate. Musaica XXVII, 101-106.

Krekovič, E. 2014: Gender identity and pottery: the size of urns in cremation cemeteries. Rei Cretariae Romanae Fautorum Acta 43, 815-817.

Neustupný, E. 1973: Jednoduchá metoda archeologické analýzy. Památky archeologické LXIV(2), 169-234.

Neustupný, E. 2007: Metoda archeologie. Plzeň: Katedra archeologie Západočeské univerzity v Plzni.

Otárola-Castillo, E., Torquato, M. G. 2018: Bayesian Statistics in Archaeology. Annual Review of Anthropology 2018, 435-453.

Pichlerová, M. 1981: Gerulata Rusovce. Rímske pohrebisko II. Bratislava: Archeologický ústav Slovenského národného múzea v Bratislave.

Pichlerová, M. 1983a: Pokračovanie výskumu v Bratislave-Rusovciach. Fortsetzung der Grabung in Bratislava-Rusovce. Archeologické výskumy a nálezy na Slovensku v roku 1982, 208-210.

Pichlerová, M. 1983b: Postavenie Gerulaty na stredodunajskom Limes Romanus. Zborník Slovenského národného múzea LXXVII. História 23, 63-94.

Pichlerová, M., Stloukal, M. 1977: Kostrové hroby z římského pohřebiště II v Gerulatě. Časopis Národního muzea v Praze. Řada př́rodovědná 146, 29-40.

Pichlerová, M., Stloukal, M. 1981: Žárové hroby z římského pohřebiště II v Gerulatě. Časopis Národního muzea v Praze. Ǩada přírodovědná 150, 184-200.

Schmidtová, J., Mathédesz, L'. 2016: Nové nálezy jednotky piatej kohorty Lucensium. In: I. Bazovský (ed.): Zborník na pamiatku Magdy Pichlerovej. Štúdie. Zborník Slovenského národného múzea. Archeológia, Supplementum 11. Bratislava: Slovenské národné múzeum v Bratislave - Archeologické múzeum, 125-130.

Schmidtová, J., Mathédesz, L’. 2018: Rímsky kastel Gerulata. In: R. Šenkirik, L. Gembešová, H. Bakaljarová, M. Škrovina (eds.): Dunajský Limes a odkaz rímskej antiky na l'avom brehu Dunaja. Bratislava: Bratislavský samosprávny kraj, Academia Istropolitana Nova, 52-66.

Schmidtová, J., Vorlíčková, B. 2006: Pokračovanie výskumu na stavbe Odkanalizovanie Rusoviec. Archeologické výskumy a nálezy na Slovensku v roku 2004, 175-177.

Senior, L. M., Birnie, D. P. 1995: Accurately estimating vessel volume from profile illustrations. American Antiquity 60(2), 319-334. DOI: 10.2307/282143. Availlable also from: www.jstor.org/stable/282143.

Varsik, V. 1996: Archäologische Topographie des antiken Gerulata. In: K. Kuzmová, J. Rajtár (eds.): Gerulata I. Nitra: Archeologický ústav Slovenskej akadémie vied v Nitre, 7-43. 
Varsik, V. 1999: Die Notgrabung einer römischen Siedlung des 2.-3. Jahrhunderts im Hinterland des Kastells Gerulata (vorläufige Ergebnisse 1995-1997). In: J. Tejral (Hrsg.): Das mitteleuropäische Barbaricum und die Krise des römischen Weltreiches im 3. Jahrhundert. Spisy Archeologického ústavu AV ČR Brno 12. Brno: Archäologisches Institut der Akademie der Wissenschaften der Tschechischen Republik Brno, 215-233.

Weber, Z. 1997: Statistická analýza archeologických dat. In: J. Macháček (ed.): Počítačová podpora v archeologii. Brno: Ústav archeologie a muzeologie Filozofické fakulty Masarykovy univerzity, 19-214.

\section{Resumé}

Antická Gerulata (Bratislava-Rusovce, Slovensko) byla vojenským táborem (později pevností) s civilním zázemím na severopanonském Limes Romanus. Existovala od 2. poloviny 1. stoletín. 1 . a zanikla na počátku 5. století (Schmidtová, Mathédesz 2018). Místní obyvatelé pohřbívali své mrtvé na několika pohřebištích (obr. 1), avšak pro tuto studii je podstatné pohřebiště č. II, kde byl prozatím prozkoumaný nejvyšší počet hrobů (obr. 2). Datováno je mezi 2. polovinu 1. století a počátek 3. století (Pichlerová 1981). Keramický soubor z této nekropole sestává ze 409 nádob (většinou se jedná o fragmenty). Pro výpočet objemů bylo použito 121 nádob (tab. 1), které se dochovaly kompletně, případně alespoň z větší části. Všechny nálezy se nacházejí v depozitáři Archeologického múzea Slovenského národného múzea (SNM).

Nádoby byly na základě tvaru klasifikovány do pěti skupin (obr. 3-12): džbány, misky a talíre, baňaté nádoby, urny a ostatní (vázy, amfory a poháry). Po vygenerování 3D modelů a výpočtu objemů následovalo testování hypotéz, které se zabývaly bud' statisticky významnými rozdíly nebo korelací mezi objemy (či tvarem nádob) a různými okolnostmi pohřebního ritu (typ pohřbu, typ hrobu, věk a pohlaví pohřbeného, datování hrobu a poloha nálezu). Tvorba modelů a výpočet objemů byly realizovány ve volně dostupném software Blender v2.79 za pomoci kresebné a fotografické dokumentace a rozměrů jednotlivých nádob. Hypotézy se testovaly za použití univariačních statistických metod ve volně dostupném software Past3 pomocí parametrických a neparametrických testů. Vizualizace frekvence a distribuce dat jsou prezentovány prostřednictvím různých grafů a diagramů (graf 1-10).

Nejvyšší průměr měly objemy džbánů a uren, nejnižší pak zase misky a baňaté nádoby. Obě dvojice keramických tvarů měly zároveň podobnou objemovou škálu. V hrobech se vyskytovaly obvykle nejvýše čtyři nádoby, přičemž nejčastější byly různé kombinace džbánu, misky/talíře a baňaté nádoby. V žárových hrobech byla zjištěna nejen výrazně vyšší frekvence nádob, ale i signifikantně vyšší průměr jejich objemů. Druhá uvedená skutečnost je však částečně způsobena př́ítomností uren, které se samožrejmě v kostrových hrobech neobjevily. Vyšší počet keramiky v kremačních hrobech koreluje i s ostatními hrobovými nálezy na pohřebišti. Je proto možné, že žárově byla pohřbívána ekonomicky silnější sociální vrstva populace (Krekovič 2011). Objemy uren dospělých jedinců byly signifikantně vyšší než objemy uren dětí, které však korelovaly s objemy uren jedinců, jejichž věk nebylo možné identifikovat. $Z$ tohoto důvodu můžeme předpokládat, že minimálně některé z věkově neurčených hrobů jsou dětské. Výskyt objemnějších nádob v hrobech dospělých jedinců byl prokázán i v případě džbánů. Zdá se, že nádoby s nejvyšším objemem dominují v hrobech dospělých mužů. Po nich následují ženské hroby a nakonec hroby dětí. Frekvence všech nádob byla naopak vyšší v hrobech žen, a zejména neurčených jedinců, přičemž značné procento zde s jistotou tvořily děti, jejichž ostatky je však složité pohlavně identifikovat. Testování pohlaví jako proměnné však bylo výrazně ovlivněno nízkým počtem identifikovaných jedinců z této nekropole.

V rámci chronologie pohřebiště nebyly zjištěny žádné významné rozdíly ve tvaru či objemu nádob. Nepatrné odlišnosti způsobila nepravidelná distribuce dat v jednotlivých časových intervalech. V poloze nálezů nebyly taktéž zaznamenány signifikantní rozdíly. V kostrových hrobech se nádoby koncentrovaly především v blízkosti lebky nebo dolních končetin zesnulého, což je standardní umístění na mnohých provinciálních pohřebištích. V kremačních hrobech se urna vyskytovala hlavně uprostřed hrobu a milodary v jeho dolní části (v případě, že ji bylo možné určit na základě orientace). Pokud by se v tvarové skupině „ostatni“ dochovalo v lepším stavu větší množství nálezů, dosáhly bychom v rámci této analýzy spíše heterogenních výsledků. I přesto jsme pomocí kombinace více metod získaly určité náznaky strukturální koherence mezi keramickými nálezy a pohřebním ritem. Některé naše hypotézy se podařilo validovat, důležité je však i to, že jiné ne (např. žádné změny v rámci jednotlivých chronologických stupňů). Ačkoliv nemůžeme interpretaci výsledků generalizovat na celý datový soubor, na určitém stupni pravděpodobnosti ji lze považovat za autentickou.

\section{Contacts}

Alina Szabová

Ústav archeologie a muzeologie

Filozofická fakulta, Masarykova univerzita

Arna Nováka 1

CZ-602 00 Brno

489437@mail.muni.cz

\section{Zuzana Porubčanová}

Ústav archeologie a muzeologie

Filozofická fakulta, Masarykova univerzita

Arna Nováka 1

CZ-602 00 Brno

489430@mail.muni.cz 